\title{
ATRAZINE LEACHING FROM BIOCHAR-AMENDED SOILS
}

\author{
A Thesis \\ Presented to the Faculty of the Graduate School \\ of Cornell University \\ in Partial Fulfillment of the Requirements for the Degree of \\ Master of Science
}

by

Kyle Brook Delwiche

May 2012 
(C) 2012 Kyle Brook Delwiche 


\begin{abstract}
The herbicide atrazine is used extensively throughout the United States for weed control, and is a widespread ground water and surface water contaminant. Biochar has been shown to strongly sorb organic compounds, and could provide a way to reduce atrazine leaching. Using lab and field experiments, we studied how biochar impacts atrazine leaching under increasingly heterogeneous soil conditions. Lab-scale soil columns dosed with biochar, atrazine, and simulated rain demonstrated that biochar application does reduce atrazine leaching. Both homogenized and undisturbed soil cores demonstrated lower atrazine leaching with biochar addition, though the increased variability in results for the undisturbed cores masked the statistical significance of this finding. We attribute increased variability to the increased complexity of the soil pore structure. Field plot treatments included biochar, acidified biochar, peat plus biochar mixture, and peat moss. Mean groundwater atrazine concentrations were 34\% and 53\% lower for biochar and acidified biochar plots, respectively, relative to the control plots; the acidified biochar plots were significantly lower $(\mathrm{p}=0.0056)$. Plots receiving peat plus biochar showed no reduction, indicating that organic matter may compete for biochar sorption sites. Peat moss alone had no effect on atrazine leaching. We conclude that biochar application has the potential to decrease atrazine leaching, but heterogeneous soil conditions may reduce this impact.
\end{abstract}




\section{BIOGRAPHICAL SKETCH}

Kyle Delwiche grew up in the Central Valley of California. Her interest in science and the environment started early in her life and led her to pursue a bachelor's degree in Civil and Environmental Engineering from the University of California, Berkeley. During her undergraduate years Kyle spent a summer at Cornell as part of the Research Experience for Undergraduates Program. After graduating in May 2007, Kyle went to work for Engeo Incorporated, an engineering consulting firm specializing in geotechnical and environmental engineering. At Engeo Kyle worked as a water resources engineer. She designed stormwater detention facilities for hydromodification and water quality treatment, monitored wetlands, and wrote engineering reports. In April of 2010 Kyle earned her Professional Engineers license in the state of California. Deciding her heart lay in academia, Kyle started her Master's degree at Cornell University in Biological and Environmental Engineering in the fall of 2010. After submitting this thesis she will graduate, get married, and move to Boston to start her $\mathrm{PhD}$ in Civil and Environmental Engineering at Massachusetts Institute of Technology. 


\section{ACKNOWLEDGEMENTS}

This material is based upon work supported by the National Science Foundation Graduate Research Fellowship under Grant No. DGE-0707428.

I would like to thank Professor Todd Walter for his unwavering support and enthusiasm for this project. I would also like to thank Brian Richards for being a constant source of ideas, advice, and practical know-how. Steve Pacenka, Shree Giri, Anthony Hay, and Johannes Lehmann all helped me significantly throughout my project, and I appreciate their willingness to answer my questions. This thesis would not exist without the help of many undergraduate researchers and my fellow graduate students working in the Soil and Water Lab - thank you all! Finally, thank you to my parents for all their emotional and intellectual support over the years, and to Joe: you are my sunshine. 


\section{Table of Contents}

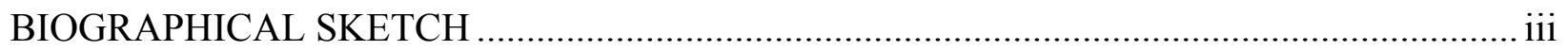

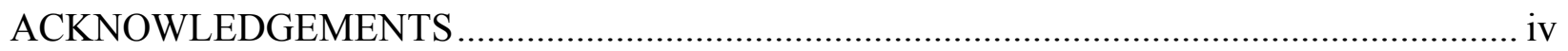

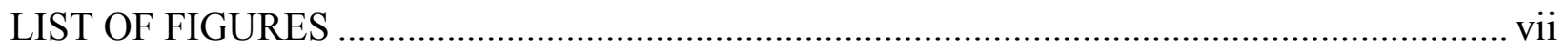

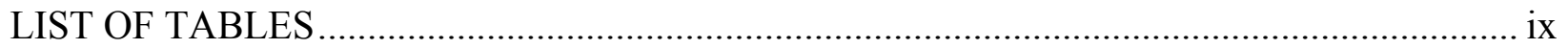

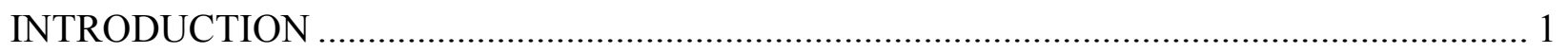

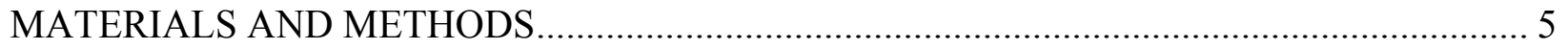

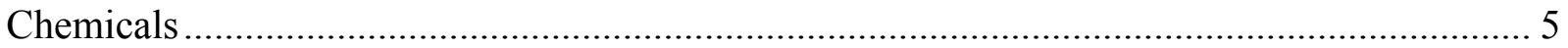

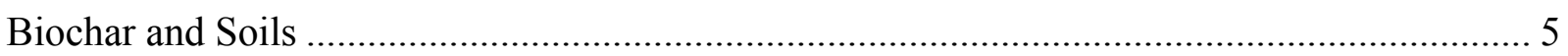

Laboratory Leaching Experiments …………………….................................................. 8

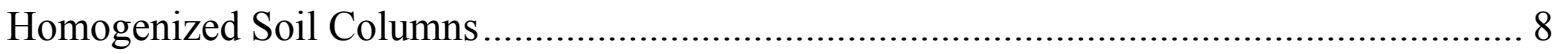

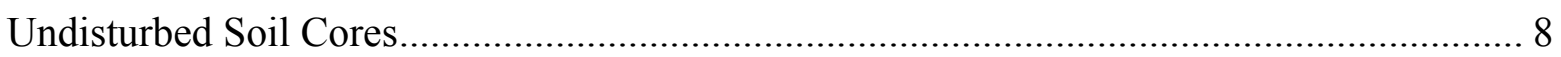

Field Leaching Experiments ......................................................................................... 9

Experimental Design ................................................................................................. 9

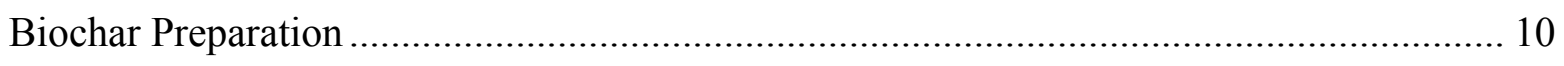

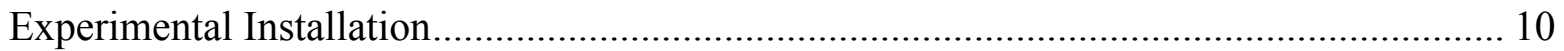

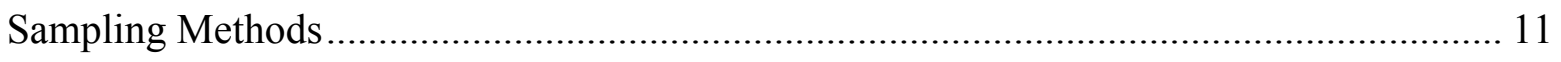

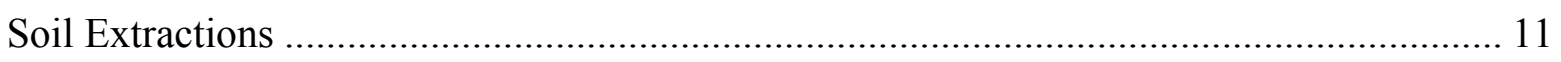

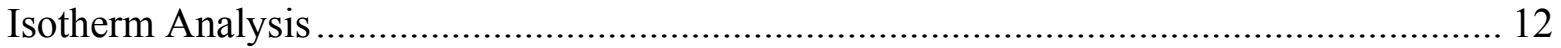

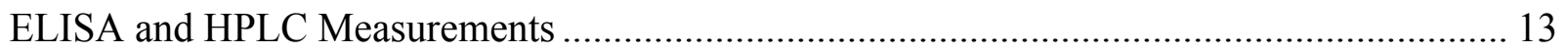

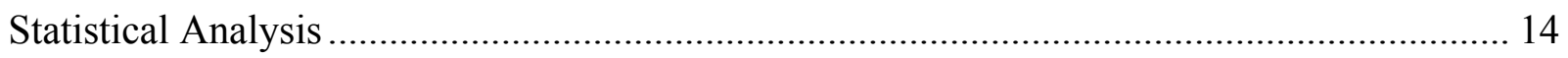

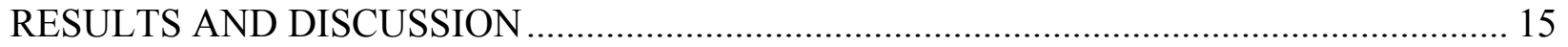

Laboratory Leaching Experiments ………………………............................................. 15

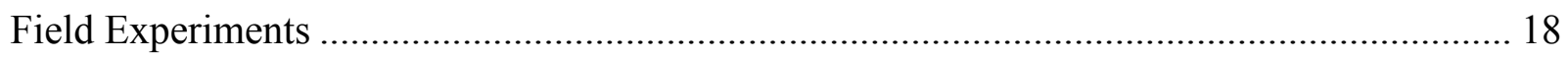

Groundwater Concentration and Soil Extraction Results.................................................. 18

Atrazine/Biochar/Peat Isotherms .................................................................................... 22

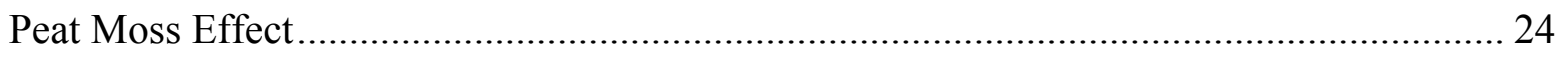

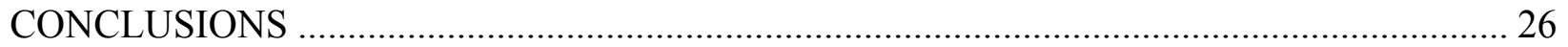

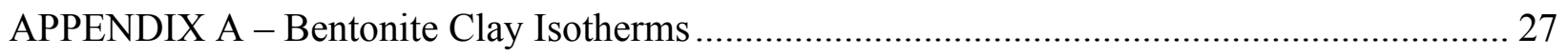




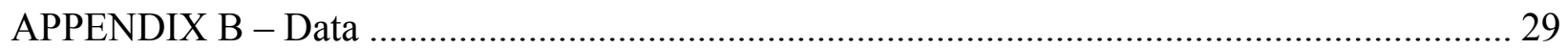

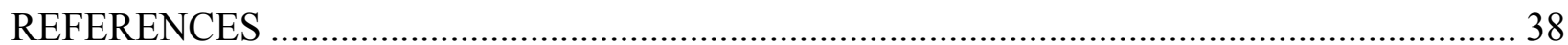




\section{LIST OF FIGURES}

Figure 1 - Location of Cornell Recreation Center (CRC) site, the location of the biochar field plots. (Page 6)

Figure 2 - Biochar plot treatment design and broader field-experiment plot layout. Column on left explains the planting design for the broader field; $\mathrm{C}=$ control, $\mathrm{SW}=$ switchgrass, $\mathrm{SW}+\mathrm{N}=$ switchgrass plus nitrogen (fertilization beginning in 2012), $C R G=$ Canary Reed Grass. (Page 7)

Figure 3 - Average cumulative atrazine leached over time, expressed as a percentage of total atrazine added, for control and biochar-treated homogenized soil columns (A) and undisturbed soil cores (B). Error bars represent standard deviation from 3 replicates. ${ }^{\mathrm{a}, \mathrm{b}}$ Statistically different, ${ }^{\mathrm{c}}$ Not statistically different. (Page 15)

Figure 4 - Atrazine concentrations measured in groundwater samples, (a); Amount of atrazine in $\mu \mathrm{g}$ extracted per $\mathrm{kg}$ of soil sample, broken out by plot treatment type (b). Boxes represent the interquartile range (IQR) and whiskers extend to 1.5 times the IQR. Data marked with hollow circles fall outside 1.5 times the IQR. (Page 18)

Figure 5 - Sorption isotherms for biochar (hollow triangle), acidified biochar (hollow circle), biochar plus peat (triangle), and acidified biochar plus peat (circle) showing sorbed atrazine in $\mu \mathrm{g} / \mathrm{mg}$ versus equilibrium concentration $(\mathrm{mg} / \mathrm{L})$. Plotted lines are derived from the Freundlich model with dashed lines for isotherms with peat and solid lines for isotherms without peat (model values in Table 5). (Page 23) 
Figure 6 - Bentonite and atrazine sorption isotherm. Horizontal axis represents equilibrium atrazine concentration in $\mu \mathrm{g} / \mathrm{L}$ and vertical axis represents amount of atrazine sorbed to bentonite in $\mu \mathrm{g} / \mathrm{g}$. Error bars are standard deviation from two samples. (Page 28) 


\section{LIST OF TABLES}

Table 1 - Average peak atrazine concentration measured in leachate and cumulative leached water volume for homogenized control and biochar columns. (Page 16)

Table 2 - Atrazine leachate concentration for the field experiment. (Page 18)

Table 3 - P-value results for nonparametric Steel-Dwass multiple comparisons of leachate atrazine concentration between treatment pairs. (Page 19)

Table 4 - P-value results from nonparametric Steel-Dwass multiple comparison results for comparisons of extracted atrazine between treatments. (Page 21)

Table 5 - Fitted Langmuir and Freundlich parameters for the biochar, acidified biochar, biochar plus peat, and acidified biochar plus peat isotherms. (Page 22)

Table 6 - Data from Homogenized Soil Column Experiment. (Page 29)

Table 7 - Data from Undisturbed Soil Column Experiment. (Page 30)

Table 8 - Atrazine Concentrations in Groundwater Samples Collected From Field Plots. (Page 31)

Table 9 - Atrazine Extracted from Field Soil Samples. (Page 33)

Table 10 - Data from atrazine/biochar isotherm study. (Page 36)

Table 11 - Data from atrazine/bentonite isotherm study. (Page 37) 


\section{CHAPTER 1}

\section{INTRODUCTION}

Pesticides are used extensively for pest and weed control in agricultural settings. While pesticides can improve crop productivity and resistance to disease, widespread use of these chemicals can lead to environmental contamination. Extensive studies conducted between 1992 and 2001 by the United States Geologic Survey detected pesticides or pesticide residues in over $90 \%$ of sampled streams and $60 \%$ of shallow groundwater taken from beneath agricultural and urban areas (Gilliom et al., 2006). Such widespread contamination raises potential concerns for human and environmental health.

Atrazine is the most commonly used herbicide in the United States and is also the most frequently detected herbicide in drinking water aquifers and shallow groundwater beneath agricultural areas (Barbash et al., 2001). Atrazine is a neutral, moderately polar organic compound based on a triazinin ring structure (Welhouse and Bleam, 1992). Using sediment samples, Sun et al., 2010, found that atrazine has a $\log$ Koc value between 1.79 and 1.95, indicating the potential for a relatively high mobility within the environment. This mobility, combined with a long half-life (3-4 months in soil), contributes to widespread atrazine contamination of water resources. Atrazine has been shown to act as an endocrine disruptor in humans (Lasserre et al., 2009). Understanding how atrazine leaches into groundwater, and identifying ways to reduce leaching rates, would represent an important gain for environmental health. 
Increasing atrazine retention within the soil profile through enhanced sorption could be one way to reduce atrazine leaching to groundwater. Recent work studying potential pesticide sorbents has found that black carbon has a high affinity for sorbing organic contaminants (Accardi-Dey and Gschwend, 2003; Lohmann et al., 2005; Yang et al., 2006; Smernik, 2009). In particular, the black carbon form known as biochar readily sorbs atrazine (Cao et al., 2009; Loganathan et al., 2009; Zheng et al., 2010). The term biochar refers to the carbon rich product formed from the pyrolysis of organic matter such as wood chips, animal wastes, and crop residues (Lehmann and Joseph, 2009; Kookana et al., 2011). Biochar incorporation into soil has been shown to improve soil fertility and to sequester atmospheric carbon in relatively recalcitrant soil deposits (Glaser et al., 2002; Lehmann et al., 2006; Chan et al., 2007; Lehmann, 2007; Lal, 2008; Sohi et al., 2010). Recent studies have examined biochar's enhanced ability to sorb pesticides and have concluded that this increased sorption could potentially decrease pesticide leaching to groundwater (Spokas et al., 2009; Zheng et al., 2010).

Despite the wealth of evidence demonstrating that biochar will readily sorb pesticides, complicating factors make it difficult to predict if this sorption will translate to less atrazine entering the groundwater. One process that could influence atrazine leaching is colloidfacilitated transport, the process by which otherwise immobilized pollutants are moved through the soil profile via adsorption to mobile colloids (Gao, 1997; Flury and Qui, 2008). Biochar has been shown to contain colloidal-sized particles, which could mobilize through soil pore water flows (Zhang et al., 2010; Abiven et al., 2011,). Multiple studies have shown that aromatic black carbon (biochar-like material produced by natural wildfires) migrates downwards through the soil profile (Skjemsted et al., 1999; Dai et al., 2005; Rodionov et al., 2006). In regards to atrazine transport, one study found that $4.9 \%-30 \%$ of total atrazine collected from field 
lysimeters was associated with colloids (Sprague et al., 2000). Cabrera et al., 2011, found that some biochar can actually increase herbicide transport, potentially through increased mobility via dissolved organic carbon. Since atrazine can associate with colloids and biochar colloids have been shown to mobilize through soil pores, there is a possibility that biochar additions to soil could increase colloid-facilitated transport of atrazine.

Considering native soil pore structure adds additional complexity to the question of how biochar will impact pesticide leaching. Previous studies have demonstrated that preferential flow through macro-pores increases contaminant movement through the soil profile (Camobreco et al., 1996; Akhtar et al., 2003). Studies have also shown that colloid-facilitated transport is enhanced by preferential flow through soil macropores (Seta and Karathanasis, 1997; Jacobsen et al., 1997; Villholth et al., 2000). If biochar particles influence atrazine leaching via colloidfacilitated transport, we would expect this effect to be enhanced by the presence of soil macropores. The above discussion of atrazine leaching and potential contributing factors leads us to the research questions we will address in this study: 1) Can increased sorption to biochar reduce atrazine leaching?, 2) Do increasingly complex soil structures impact atrazine leaching?, and 3) Does increased facilitated transport offset any potential reduction in atrazine leaching due to biochar addition?

In order to address these questions and increase our understanding of whether or not biochar use could help mitigate atrazine leaching, we designed a series of three experiments with increasing complex soil conditions. The progression of experiments began with homogeneous, packed soil columns to study atrazine leaching in a simplified soil structure. We then used undisturbed soil cores to see if the presence of macro-pores changed biochar's impact on atrazine 
leaching. Finally, we used field-scale plot treatments to determine if biochar could impact atrazine leaching in the most heterogeneous, real-world conditions. In addition to the biochar and control treatments used in the laboratory experiments, we added three additional soil treatments to the field study. These three additional treatments included an acidified biochar treatment, peat plus biochar, and peat alone. The acidified biochar treatment was chosen to determine if the biochar surface $\mathrm{pH}$ influenced results. The peat and peat plus biochar treatments were included to see if the organic matter content of the soil would alter any impact of biochar on atrazine leaching. Previous research suggests that soil organic matter may also sorb to biochar and could compete with atrazine for adsorption sites (Xing et al., 1996; Qiu, 2009). The peat treatment will act as a control for the peat plus biochar treatment. 


\section{CHAPTER 2}

\section{MATERIALS AND METHODS}

\section{$\underline{\text { Chemicals }}$}

The atrazine product AAtrex(C) Nine-OC produced by Syngenta was acquired from Cornell Farm Services. The product comes in the form of water-dispersible granules and is $88.2 \%$ atrazine (2-chloro-4-ethylamino-6-isopropylamino-s-triazine). The atrazine product has a $\mathrm{pH}$ of 8.5 , a solubility in water of $33 \mathrm{mg} / \mathrm{L}$ at $20^{\circ} \mathrm{C}$, and a specific gravity of $0.48 \mathrm{~g} / \mathrm{cm}^{3}$.

\section{$\underline{\text { Biochar and Soils }}$}

We used two different batches of biochar for these experiments, both purchased from Biochar Solutions Inc. (then Biochar Engineering Corporation). We purchased a smaller batch for the homogenized soil column trials, and then a larger batch for the field experiment and undisturbed soil columns. Both batches were produced from similar feedstock of wood chips, primarily from pine trees. Biochar Solutions produces biochar for commercial sale using a proprietary, two-stage process. During the first stage, wood chip feedstock is carbonized in an oxygen-limited environment at $700-750^{\circ} \mathrm{C}$ for less than one minute. The material is then passed to the second stage where it is held in a sweep gas environment between $400-550{ }^{\circ} \mathrm{C}$ for approximately 10-14 minutes. No oxygen is available during the second stage. We determined that the biochar used in the field experiment had a surface $\mathrm{pH}$ of 8.5 , a nitrogen content of $0.04 \%$ and a carbon content of $88.09 \%$. 


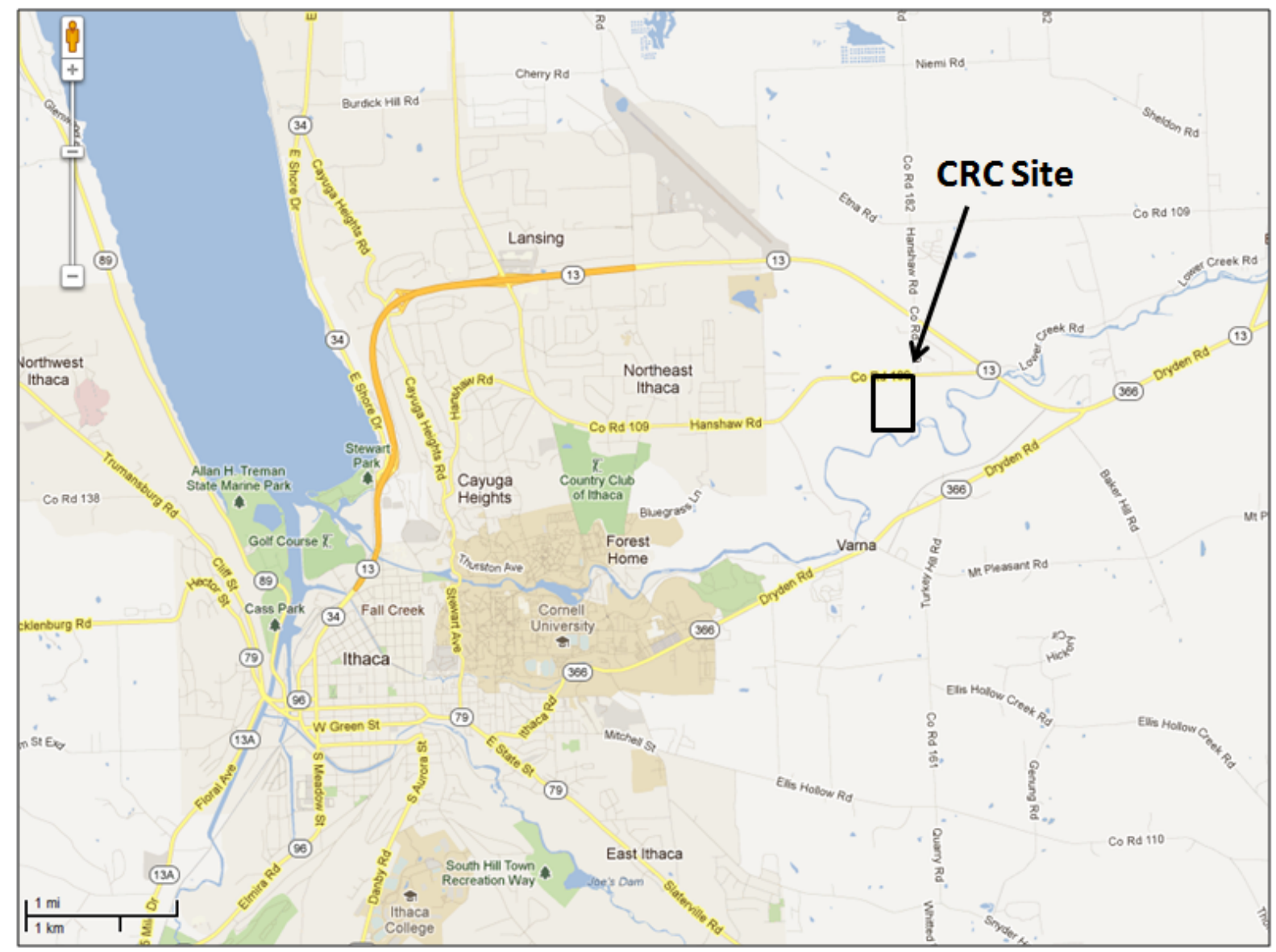

Figure 1 - Location of Cornell Recreation Center (CRC) site, the location of the biochar field plots.

The soil used for the soil column experiments came from the Cornell Recreation Center (CRC) site (Figure 1), which is also where we installed the biochar test plots. The CRC site encompasses 6.5 ha that, due to poor drainage conditions and modest soil fertility, has been historically underutilized. As part of a broader study looking at perennial grass bioenergy production, we incorporated our biochar treatment plots into a portion of the field being planted with switchgrass seeds (Figure 2). According to a detailed soil survey published by Cornell in 
1966, the soils present in our treatment plots are classified as Canaseraga channery silt loam (Cline, 1966). These soils are characterized by an upper silty mantle typically between $0.45 \mathrm{~m}$ and $1.0 \mathrm{~m}$ deep. Underlying the silt mantle is a fragipan layer that extends downwards to approximately 1.5 meters, past which is a firm glacial till. The slope is generally flat, with localized depressions. Laboratory tests show that the soil $\mathrm{pH}$ is 5.6.

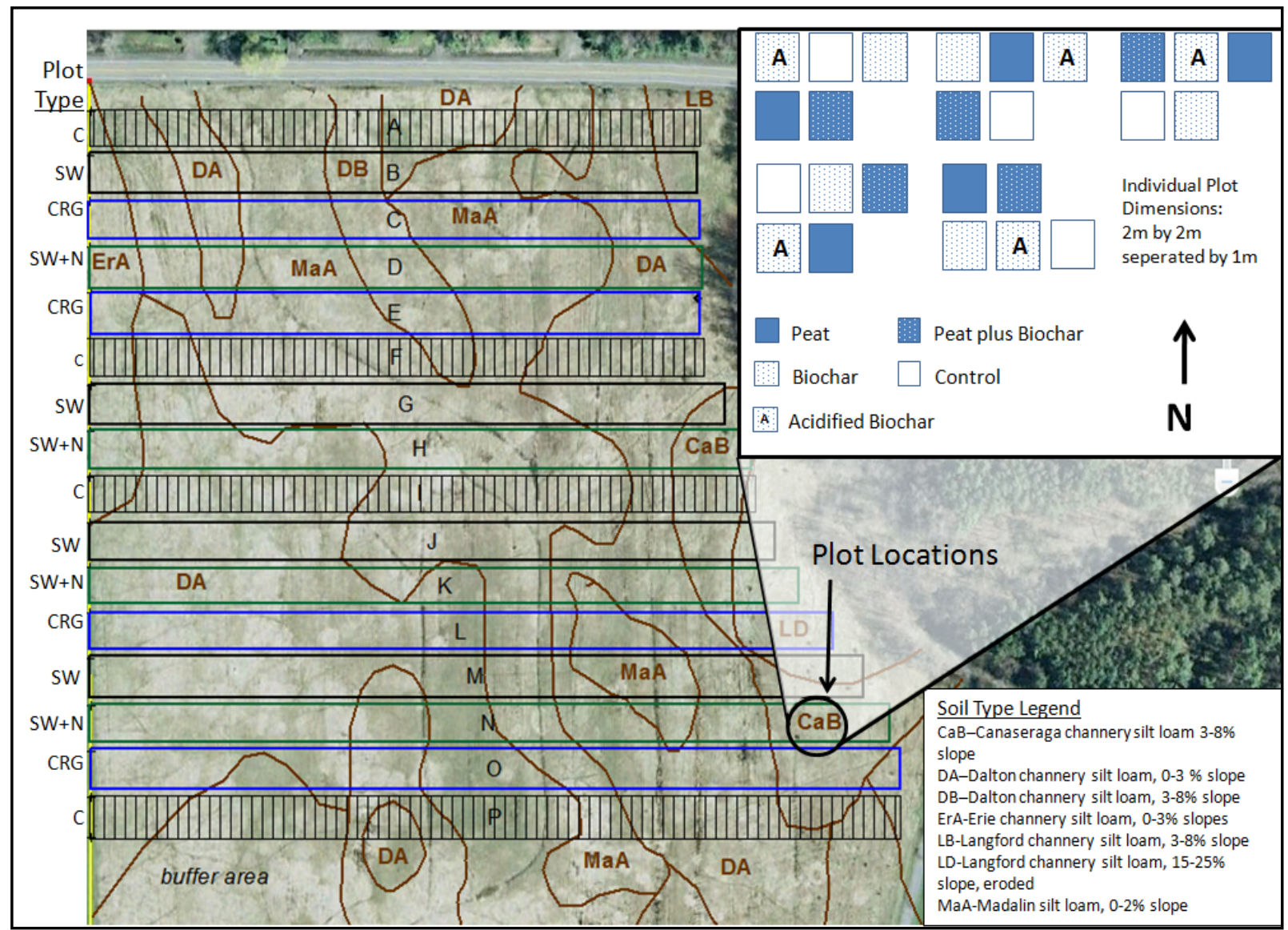

Figure 2 - Biochar plot treatment design and broader field-experiment plot layout. Column on left explains the planting design for the broader field; $\mathrm{C}=$ control, $\mathrm{SW}=$ switchgrass, $\mathrm{SW}+\mathrm{N}=$ switchgrass plus nitrogen (fertilization beginning in 2012), CRG = Canary Reed Grass. 


\section{Laboratory Leaching Experiments}

\section{Homogenized Soil Columns}

Soil for homogenized soil columns was extracted from the CRC field site and allowed to air dry inside the laboratory. Large soil aggregates were broken up mechanically, and soil was passed through a $2.8 \mathrm{~mm}$ sieve. To improve infiltration capacity, soil was mixed 50/50 by weight with industrial quartz sand. The soil/sand mixture was then loaded into $32 \mathrm{~cm}$ tall and 10 $\mathrm{cm}$ diameter PVC pipes. The soil column was capped on the bottom and perforated to allow leachate to pass through, and a $200 \mathrm{~g}$ quartz sand bottom layer prevented soil migration into the leachate.

Biochar surface application and control treatments were run simultaneously and in triplicate. Biochar columns were each amended with $8 \mathrm{~g}$ dry biochar, consistent with a field application rate of $10 \mathrm{~T} / \mathrm{ha}$. The biochar was mixed in to approximately the top $4 \mathrm{~cm}$ of soil. The top $4 \mathrm{~cm}$ of control column soil were similarly mixed for consistency. We then applied $0.85 \mathrm{mg}$ atrazine dissolved in $40 \mathrm{~mL}$ deionized water to each column, consistent with a field application rate of $1.1 \mathrm{~kg} /$ hectare. Next we applied tap water at an average rate of $0.75 \mathrm{~L} / \mathrm{hr}$ per column for 9 hours and periodically collected water samples from column leachate. All samples were filtered to $0.45 \mu \mathrm{m}$ and frozen until analysis.

\section{Undisturbed Soil Cores}

We next studied the impact of soil pore structure on atrazine leaching by using undisturbed soil cores extracted from the CRC field site. These soil cores were approximately 18 $\mathrm{cm}$ in diameter and $30 \mathrm{~cm}$ long, with small variations caused by heterogeneous, rocky soil conditions. Cores were extracted from the top soil layer as described in previous research by 
Camobreco et al., 2006 and Akhtar et al., 2003. Cores were stored in a temperature controlled laboratory and periodically watered prior to experimental use.

In preparation for experimental run, we drip-irrigated the soil cores until observing the onset of water seepage. Three cores were then dosed with 24.8 grams of biochar mixed into the top $7 \mathrm{~cm}$ of soil surface, equivalent to $10 \mathrm{~T} / \mathrm{ha}$. We also mixed the top soil in control columns for consistency. All six cores received $6.29 \mathrm{mg}$ of atrazine in $50 \mathrm{~mL}$ of deionized water applied via spray bottle, equivalent to the $2.2 \mathrm{~kg} /$ hectare. We used a rainfall simulator with 23 gauge blunt nosed needles to produce artificial raindrops. Each column received artificial rain at a rate of $0.96 \mathrm{~mL} / \mathrm{hr}$ and we periodically collected water samples from the leachate. Due to space constraints, we ran 2 columns at a time on three separate days (one biochar treatment and one control per day). All samples were filtered to $0.45 \mu \mathrm{m}$ and frozen until analysis.

\section{Field Leaching Experiments}

\section{Experimental Design}

As described above, our field plots were incorporated into a broader five year study on perennial grass biofuels production in marginal farmland. For plot treatments we chose the control and biochar conditions studied in the lab. We also included three additional soil treatments to maximize the information we could glean from the field plots. These three additional soil treatments were acidified biochar, peat moss, and peat moss plus biochar. The peat moss treatments were included to study how higher organic matter in soils could affect biochar impacts on atrazine leaching. The acidified biochar treatment was included to determine if the surface $\mathrm{pH}$ of the biochar was a significant factor in atrazine leaching. The 5 treatments were each repeated in 5 blocks, using a randomized Latin square design to ensure the treatments 
were never in the same position within each block (Figure 2). All treatments plots were 2 meters by 2 meters, separated from each other by 1 meter. Preliminary chloride tracer experiments had demonstrated minimal lateral groundwater flow between wells 1 meter apart over a 24 hour period.

\section{Biochar Preparation}

We prepared the acidified biochar by soaking biochar in a $\mathrm{pH} 1.4$ solution of hydrochloric acid. After 24 hours, the acidic solution was drained and the biochar was rinsed once with tap water. The $\mathrm{pH}$ measurements on the rinse water indicated that the biochar surface $\mathrm{pH}$ had dropped from approximately 8.5 to 6.8 . For consistency, the non-acidified biochar was soaked in tap water and drained after 24 hours.

\section{Experimental Installation}

Prior to the experimental installation, the field was mechanically mowed, plowed, and disced. To apply the biochar and peat moss, we hand-spread the materials across the $4 \mathrm{~m}^{2}$ plots. Each plot received the equivalent of $4 \mathrm{~kg}$ of dry biochar, consistent with a loading rate of 10 $\mathrm{T} / \mathrm{ha}$. Peat moss was applied at a rate of $3.75 \mathrm{~kg}$ per square meter. After hand application, biochar and peat moss were raked into the top 5-10 $\mathrm{cm}$ of soil.

Immediately after biochar and peat moss installation, the switchgrass seeds were mechanically broadcasted across the plots. We then installed 4 shallow groundwater wells per plot for a total of 100 wells. Wells consisted of $3.8 \mathrm{~cm}$ diameter PVC pipe, drilled with numerous holes for the bottom $\sim 60 \mathrm{~cm}$, and wrapped in screen. We used a tractor mounted drill rig to drill $1.2 \mathrm{~m}$ deep holes for well installation $(1.2 \mathrm{~m}$ being approximately sufficient to intersect the fragipan layer). Gaps in between the well and soil were packed with pea gravel and 
surface-capped with bentonite clay to reduce water flow into the gravel pack. On August 4, 2011 we applied atrazine at a rate of $2.2 \mathrm{~kg} / \mathrm{ha}$ using a backpack sprayer.

\section{Sampling Methods}

We collected groundwater samples at the first occasion when there was sufficient water in the majority of wells. This occurred on August 30,2011, 48 hours after $3.8 \mathrm{~cm}$ of rain fell courtesy of Hurricane Irene (rainfall amounts acquired from Accuweather website). The 48 hour interval between rainfall and sampling was close enough to the 24 hour interval used in the tracer experiment that we did not expect significant lateral groundwater flow to have occurred. Samples were collected by lowering a $50 \mathrm{~mL}$ Teflon centrifuge tube into each well. Samples were filtered to $0.45 \mu \mathrm{m}$ and frozen until analysis.

\section{Soil Extractions}

In addition to groundwater samples we extracted soil samples to test for residual atrazine content. The soil samples were taken in December, 2011. Samples were taken from the top 15 $\mathrm{cm}$ using a $2 \mathrm{~cm}$ diameter hand-coring device. We gathered 4 samples per plot and air dried the samples in the laboratory. Samples were ground and sieved to $2 \mathrm{~mm}$, and 5 grams of each were weighed into a $50 \mathrm{~mL}$ Teflon centrifuge tube. We then added $15 \mathrm{~mL}$ of 75:25 MeOH: $\mathrm{H}_{2} \mathrm{O}$ solution and placed the tubes horizontally on a shake table. Samples were shaken for 24 hours, allowed to settle for several hours, and then filtered with $0.2 \mu \mathrm{m}$ nylon syringe filters. A small subset of soil samples was extracted in duplicate and spiked with $5 \mu \mathrm{g}$ of atrazine to assess extraction efficiency and precision. Duplicate tests for extractions were within $8 \%$ of each other, and spiked samples were within $4 \%$ of the expected value. Samples were stored in the refrigerator prior to analysis. 


\section{Isotherm Analysis}

We conducted isotherm tests to determine the atrazine sorption affinity of the biochar. We conducted 4 types of isotherms with biochar: biochar, acidified biochar, biochar plus peat, and acidified biochar plus peat. For all isotherms, we used $25 \mathrm{~mL}$ of $0.1,1,2,5,10$, and $20 \mu \mathrm{g} / \mathrm{L}$ atrazine in $0.01 \mathrm{M} \mathrm{CaCl}_{2}$. All biochar was oven dried, ground, and sieved to $250 \mu \mathrm{m}$. For the biochar and acidified biochar isotherm tests we used 0.050 grams of biochar per $25 \mathrm{~mL}$ solution. For the peat plus biochar isotherms we used 0.050 grams biochar and 0.050 grams peat (peat ground and sieved to $250 \mu \mathrm{m})$. All isotherm samples were shaken horizontally for 24 hours, centrifuged, and filtered to $0.45 \mu \mathrm{m}$. Samples were then analyzed using the HPLC method.

We fitted the isotherms to the Freundlich model:

$$
q=K_{f} c_{e q}^{N}
$$

and Langmuir model:

$$
q=\frac{b K_{L} c_{e q}}{1+K_{L} c_{e q}}
$$

where $q$ is the amount sorbed, $c_{e q}$ is the equilibrium concentration and $K_{F}, K_{L}, b$ and $N$ are positive adjustable parameters ( $N$ constrained to lie between 0 and 1) (Essington, 2004).

Concerned about apparent bentonite migration downwards and into water samples collected from field plots, we also conducted an isotherm analysis for atrazine and bentonite. Results are included in Appendix A. 


\section{ELISA and HPLC Measurements}

Samples were analyzed using the RaPID Assay® Atrazine Test Kit available from Strategic Diagnostics (recently acquired by Modern Water). The test kit uses the principles of the enzyme linked immunosorbent assay (ELISA) method. Samples were mixed first with an enzyme conjugate and then with paramagnetic particles affixed with atrazine specific antibodies. The atrazine within the sample and the enzyme conjugate compete for binding sites on the paramagnetic particles. The paramagnetic particles are then separated from the solution using a magnetic field, and the presence of atrazine is detected by adding the enzyme substrate (hydrogen peroxide) followed by the chromogen (3,3', 5,5' tetramethylbenzinide). The resulting mixture becomes colored in response to the presence of the enzyme conjugate. Due to the initial competition for binding between the atrazine in the sample and the enzyme conjugate, a darker mixture color indicates less atrazine was present in the original sample. Samples are analyzed using a spectrophotometer at a wavelength of $450 \mathrm{~nm}$ and quantified by comparison to a standard curve. The ELISA lower detection limit is $0.05 \mu \mathrm{g} / \mathrm{L}$ and the upper limit is $5.0 \mu \mathrm{g} / \mathrm{L}$. All samples above $5.0 \mu \mathrm{g} / \mathrm{L}$ were diluted prior to analysis with deionized water, and all samples measurements were performed in duplicate. Duplicate samples with a coefficient of variation above $10 \%$ were considered errant and re-analyzed.

Samples from the soil extraction procedure, the biochar isotherms, and a subset from the groundwater sampling were analyzed using a high performance liquid chromotograph (HPLC). We used a Shimadzu SIL-10advp injector connected to a Shimadzu SPD-10avp UV-VIS detector and a Chromolith Performance RP-18e 100-4.6mm column. Using an isocratic mobile phase of 50:50 methanol and deionized water, we were able to detect atrazine concentrations from 10 $\mu \mathrm{g} / \mathrm{L}$ to $20,000 \mu \mathrm{g} / \mathrm{L}$ using a detection wavelength of $222 \mathrm{~nm}$. We also conducted a comparison 
between the ELISA results and HPLC results, and found that the HPLC results were within $8 \pm 6$ $\%$ of the ELISA results.

\section{$\underline{\text { Statistical Analysis }}$}

Statistical analysis was conducted using the proprietary statistical software JMP® (produced by SAS Institute Inc.). If data sets failed to conform to normality assumptions, we used the nonparametric Kruskal-Wallis and Steel-Dwass methods to detect significant results within the data. For data conforming to normality assumptions, we used the standard one-way analysis of variance (ANOVA) methods. We also used JMP for linear regression and checking that model residuals met the appropriate normality assumptions. We used the free-ware program $\mathrm{R}$ to calculate the $\mathrm{R}^{2}$ coefficients for the Freundlich and Langmuir models used in the isotherm analysis. 


\section{CHAPTER 3}

\section{RESULTS AND DISCUSSION}

\section{Laboratory Leaching Experiments}
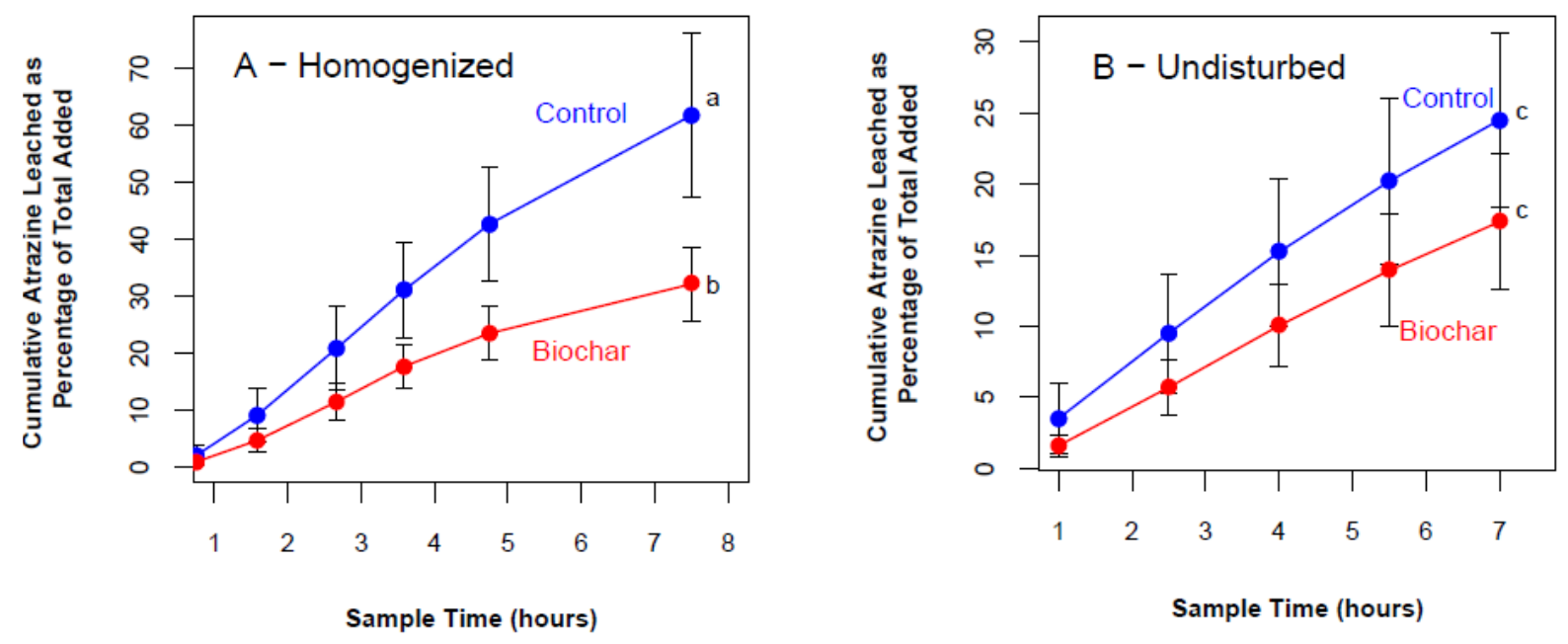

Figure 3. Average cumulative atrazine leached over time, expressed as a percentage of total atrazine added, for control and biochar-treated homogenized soil columns (A) and undisturbed soil cores (B). Error bars represent standard deviation from 3 replicates. ${ }^{\mathrm{a}, \mathrm{b}}$ Statistically different, ${ }^{\mathrm{c}}$ Not statistically different.

Biochar amendments to homogenized soil columns resulted in significantly lower total atrazine leaching $(\mathrm{p}=0.0298)$ (Figure 3a). For all but the first two sampling events, the average atrazine concentration in the control column leachate was higher than in the biochar column leachate $(\mathrm{p}<0.05)$. The biochar columns also had a statistically lower peak atrazine concentration (Table 1, $\mathrm{p}=0.0193$ ). After the peak, concentration values declined until the final sample was taken 7.5 hours after leaching began (approximately $6 \mathrm{~L}$ of total water leached per 
column). These results indicate that in a simple, packed soil condition, biochar can reduce atrazine leaching.

Table 1 - Average peak atrazine concentration measured in leachate and cumulative leached water volume for homogenized control and biochar columns.

\begin{tabular}{|lll|}
\hline Column & $\begin{array}{l}\text { Peak Atrazine Concentration }- \\
\text { Homogenized Columns }(\mu \mathrm{g} / \mathrm{L})\end{array}$ & $\begin{array}{l}\text { Peak Atrazine Concentration }- \\
\text { Undisturbed Soil Cores } \\
(\mu \mathrm{g} / \mathrm{L})^{1}\end{array}$ \\
\hline $\begin{array}{ll}\text { Control } \\
\text { Biochar Treatment }\end{array}$ & $\begin{array}{l}140.7 \pm 20.3^{\mathrm{a}} \\
78.3 \pm 8.4^{\mathrm{b}}\end{array}$ & $204.0 \pm 68.8$ \\
\hline${ }^{1}$ Undisturbed soil cores were sprayed with the equivalent of $2.2 \mathrm{~kg} / \mathrm{ha}$ atrazine compared to $1.1 \mathrm{~kg} / \mathrm{ha}$ atrazine used \\
in homogenized columns. ${ }^{\text {a,b }}$ Statistically different means.
\end{tabular}

We see similar trends when comparing the undisturbed soil core results to the homogenized columns. As before, the control cores have a higher average leached atrazine amount than the biochar cores (Figure 3b). The biochar-amended cores also had a lower peak atrazine concentration in leachate (Table 1). For all cores, the atrazine concentration in the leachate dropped between all consecutive samples after the peak. The main difference between the undisturbed and homogenized data is that the difference in cumulative atrazine leached is not significant for the undisturbed cores. The addition of soil macro-pores both increases the variability in atrazine leaching and decreases the difference in average leached atrazine between treatments.

The differences between the homogenized and undisturbed columns indicate that soil macro-pore structure plays a significant role in controlling atrazine leaching. For example, one of the control cores experienced the peak atrazine concentration in leachate in the first sample 
$(447.6 \mu \mathrm{g} / \mathrm{L})$, which was much higher than the average first value for the other two control columns $(83 \mu \mathrm{g} / \mathrm{L})$. This rapid leaching event could have been caused by local macro-pore structure. Previous studies have found that preferential flow through macro-pores is an important factor controlling pesticide leaching (Flury, 1996; Jarvis, 2007). In addition to the increased variability, we also see that the effect of biochar on atrazine leaching is diminished in the presence of macropores. While this could be because increased leaching via preferential flow offsets decreased leaching due to biochar, we would expect that macro-pores would increase the leaching potential in both un-amended and biochar amended columns.

Since leaching increased in biochar-amended cores compared to un-amended cores there may be an interaction effect between the biochar amendments and macropores. This could be evidence that biochar increased colloid-facilitated transport of atrazine via macropores. A study by Seta and Karathanasis, 1997, found that soil colloids increased atrazine transport 2 to $18 \%$, and transport was greatest in soils with well-developed macro-pore systems. Authors de Jonge et al., 2000, found that in undisturbed columns, colloid-facilitated transport accounted for $1-52 \%$ of glyphosate transport. These studies demonstrate the potential for preferential flow to enhance colloid-facilitated transport. This phenomenon may explain the atrazine leaching patterns we observed between biochar-amended columns either with or without macro-pores. 


\section{Field Experiments}

\section{Groundwater Concentration and Soil Extraction Results}

Table 2 - Atrazine leachate concentration for the field experiment.

\begin{tabular}{|lll|}
\hline Treatment & Sample Size & Mean Concentration $(\mu \mathrm{g} / \mathrm{L})$ \\
\hline Acidified Biochar & 14 & $36.8 \pm 19.5$ \\
Biochar $^{\text {a }}$ & 15 & $75.1 \pm 64.8$ \\
Peat & 18 & $79.4 \pm 40.2$ \\
Peat plus Biochar & 13 & $92.5 \pm 36.3$ \\
Control & 13 & $79.5 \pm 37.1$ \\
\hline
\end{tabular}

${ }^{\mathrm{a}}$ When omitting the two outlying data points, the sample size becomes 13 and the mean concentration is $52.0 \pm$ $23.6 \mu \mathrm{g} / \mathrm{L}$.
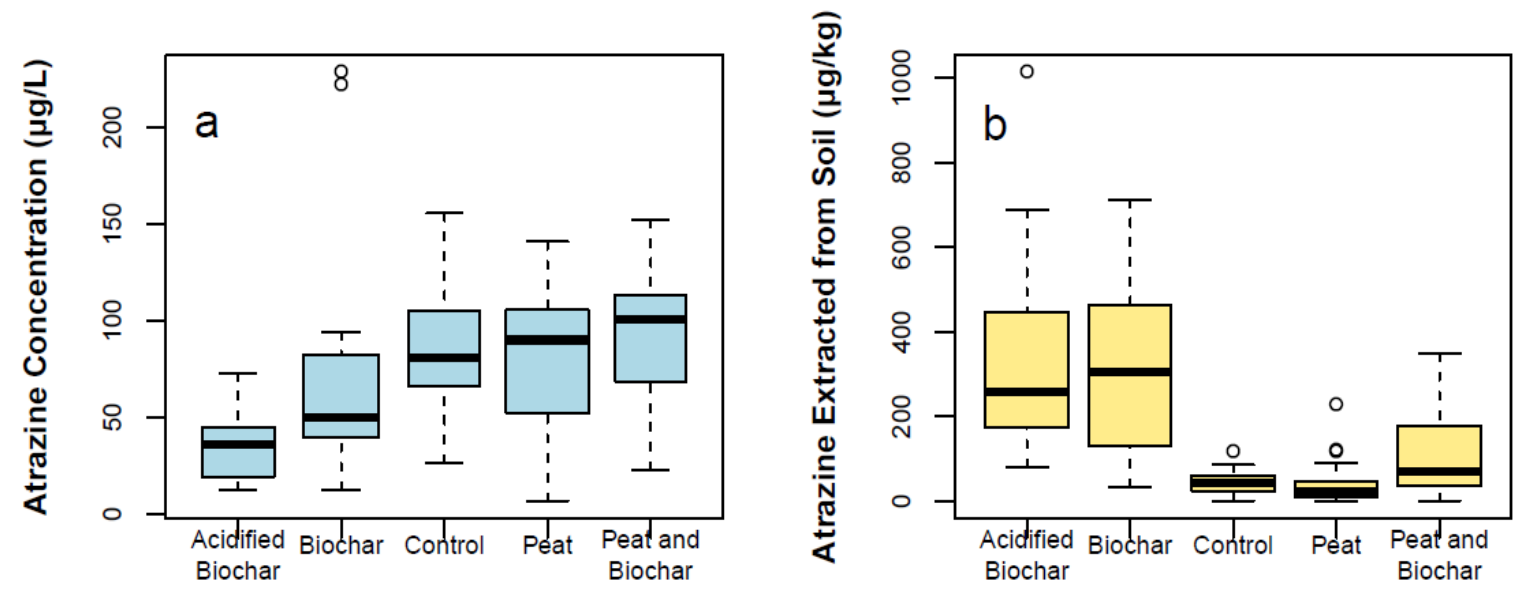

Figure 4. Atrazine concentrations in $\mu \mathrm{g} / \mathrm{L}$ measured in groundwater samples, (a); Amount of atrazine in $\mu \mathrm{g}$ extracted per $\mathrm{kg}$ of soil sample, broken out by plot treatment type (b). Boxes represent the interquartile range (IQR) and whiskers extend to 1.5 times the IQR. Data marked with hollow circles fall outside 1.5 times the IQR.

During the August 30th, 2011 sampling event, 73 of the 100 wells had sufficient water for sampling (Table 2). Our analysis results indicate that the control, peat, and peat plus biochar treatments have similar atrazine concentrations in leachate (Table 2). The acidified biochar 
leachate and biochar leachate both had lower atrazine concentrations. We also note the observation of two atrazine concentration outliers in the biochar treatment samples (Figure 4a). These data points are far above the third highest data point found in a control sample. These two outlying points reflect the large variation in atrazine leaching observed in undisturbed soil cores used in the laboratory experiments. As with the laboratory columns, this large variation could be attributed to local macro-pore structure that influences chemical transport processes within the soil. We will present statistical analysis with and without these outliers to maximize our ability to draw conclusions from the data.

Table 3 - P-value results for nonparametric Steel-Dwass multiple comparisons of leachate atrazine concentration between treatment pairs.

\begin{tabular}{|c|c|c|}
\hline Comparison Pair & $\begin{array}{l}\text { Steel-Dwass } \\
\text { Comparisons }\end{array}$ & $\begin{array}{l}\text { Steel-Dwass } \\
\text { Comparisons Omitting } \\
\text { Biochar Outliers }^{\mathrm{a}}\end{array}$ \\
\hline $\begin{array}{l}\text { Peat plus Biochar/Acidified } \\
\text { Biochar }\end{array}$ & $0.0033^{\mathrm{b}}$ & $0.0033^{\mathrm{b}}$ \\
\hline Control / Acidified Biochar & $0.0056^{\mathrm{b}}$ & $0.0056^{\mathrm{b}}$ \\
\hline Peat / Acidified Biochar & $0.0336^{\mathrm{b}}$ & $0.0336^{\mathrm{b}}$ \\
\hline Biochar/Acidified Biochar & 0.1949 & 0.4199 \\
\hline Peat plus Biochar / Biochar & 0.2988 & $0.0386^{\mathrm{b}}$ \\
\hline Control / Biochar & 0.5794 & 0.1423 \\
\hline Peat / Biochar & 0.7657 & 0.2555 \\
\hline Peat plus Biochar / Peat & 0.9470 & 0.9470 \\
\hline Peat plus Biochar / Control & 0.9861 & 0.9861 \\
\hline Peat / Control & 0.9990 & 0.9990 \\
\hline
\end{tabular}

${ }^{\mathrm{a}}$ Comparisons conducted omitting the 2 outlying data points in the biochar sample set (circles in Figure 4a).

${ }^{b}$ The means of these two treatment are significantly different $(p<0.05)$. 
Using the nonparametric Kruskal-Wallis method (data did not meet the normality requirements necessary to conduct an ANOVA), we found that the treatment effect was significant with or without the outliers included ( $\mathrm{p}=0.0011$ and $\mathrm{p}=0.0002$, respectively). We then conducted multiple comparisons using the nonparametric Steel Dwass method (equivalent to the parametric Tukey HSD method) to determine which treatment pairs were different. The acidified biochar treatment is statistically different from all other treatments except the biochar treatment (Table 3). The biochar treatment itself is statistically the same as all other treatments, except peat plus biochar, when excluding the outliers.

The standard deviations around the mean concentrations (Table 2) show that there is large overall variability between samples in the same treatment group. This variability indicates that local heterogeneities within the soil structure can greatly impact the concentration of atrazine leached. We believe these heterogeneities are also responsible for the anomalously large leaching values found in the laboratory undisturbed cores and the 2 outlying samples from the biochar plots. Prior research has demonstrated the importance of micro/macro pore structure on chemical transport within the soil (Camobreco et al., 1996; Akhtar et al., 2003). The variability we observed would support the idea that atrazine transport is influenced by the local soil pore structure. This conclusion is further supported by the fact that variability increased between the homogenized and undisturbed column laboratory experiments.

Figure $4 \mathrm{~b}$ shows that the soil extraction results are inversely related to the atrazine concentrations measured in leachate. Soil atrazine concentrations are highest for the biochar and acidified plots, the same plots that experienced the lowest average atrazine leaching. The SteelDwass multiple comparisons demonstrate that both the biochar and the acidified biochar plots 
have significantly more atrazine in the surface soil than the control, peat, and peat plus biochar plots (Table 4). The peat plus biochar average atrazine extracted is higher than for peat and control, but this effect is not statistically significant (Table 4) and requires further investigation. These results signify that the reduction in atrazine leaching observed for the acidified biochar occurred because more of the atrazine was held within the soil profile. Recent work with $\mathrm{C}^{14}$ labeled simazine found that biochar-induced reduction in simazine leaching corresponded with simazine accumulation around biochar particles (Jones et al., 2011). Other studies have also found that adding biochar to soils increases pesticide concentrations near soil surface (Yu et al., 2009). Based on our results and previous studies, we attribute the observed reductions in atrazine leachate concentrations to an increased accumulation of atrazine within the soil profile.

Table 4 - P-value results from nonparametric Steel-

Dwass multiple comparison results for comparisons of extracted atrazine between treatments.

\begin{tabular}{|ll|}
\hline Comparison Pair & $\begin{array}{l}\text { Steel-Dwass } \\
\text { Comparisons }\end{array}$ \\
\hline Peat plus Biochar/Acidified Biochar & $0.0008^{\mathrm{b}}$ \\
Control / Acidified Biochar & $<0.0001^{\mathrm{b}}$ \\
Peat / Acidified Biochar & $<0.0001^{\mathrm{b}}$ \\
Biochar/Acidified Biochar & 0.9999 \\
Peat plus Biochar / Biochar & $0.0108^{\mathrm{b}}$ \\
Control / Biochar & $<0.0001^{\mathrm{b}}$ \\
Peat / Biochar & $<0.0001^{\mathrm{b}}$ \\
Peat plus Biochar / Peat & $0.0611^{\mathrm{b}}$ \\
Peat plus Biochar / Control & 0.3583 \\
Peat / Control & 0.6567 \\
\hline
\end{tabular}




\section{Atrazine/Biochar/Peat Isotherms}

The results for atrazine concentration in leachate show that acidified biochar produces a statistically significant reduction in atrazine leaching compared to control, peat, and peat plus biochar treatments (Table 3). Regular biochar does not have this statistical effect, although it does appear to have systematically reduced atrazine leaching. This leads to the question of whether the acidified biochar actually behaves differently from the regular biochar, and what might contribute to this difference. In order to gain more insight into the sorption capabilities of acidified biochar versus biochar we conducted sorption isotherms with biochar, peat, and atrazine. This isotherm study included untreated and acidified biochar, as well as untreated and acidified biochar plus peat. Results presented in Figure 5 show that the acidified biochar appears to be slightly better at sorbing atrazine than the regular biochar both with and without peat.

Table 5- Fitted Langmuir and Freundlich parameters for the biochar, acidified biochar, biochar plus peat, and acidified biochar plus peat isotherms.

\begin{tabular}{|ll|cc|cccccc|}
\hline & & \multicolumn{2}{|c|}{ Biochar } & $\begin{array}{c}\text { Acidified } \\
\text { Biochar }\end{array}$ & $\begin{array}{c}\text { Biochar Plus } \\
\text { Peat }\end{array}$ & $\begin{array}{c}\text { Acidified } \\
\text { Biochar Plus } \\
\text { Peat }\end{array}$ \\
\hline Model & Parameter & Value & $\mathrm{R}^{2}$ & Value & $\mathrm{R}^{2}$ & Value & $\mathrm{R}^{2}$ & Value & $\mathrm{R}^{2}$ \\
\hline Freundlich & $K_{f}(\mu \mathrm{g} / \mathrm{mg})(\mathrm{L} / \mathrm{mg})^{\mathrm{N}}$ & 0.777 & 0.966 & 1.402 & 0.956 & 0.958 & 0.983 & 1.131 & 0.983 \\
& $N$ & 0.749 & & 0.553 & & 0.538 & & 0.500 & \\
Langmuir & $K_{L}(\mathrm{~L} / \mathrm{mg})$ & 0.016 & 0.964 & 0.069 & 0.940 & 0.130 & 0.944 & 0.176 & 0.928 \\
& $b(\mu \mathrm{g} / \mathrm{mg})$ & 30.78 & & 12.59 & & 6.26 & & 6.00 & \\
\hline
\end{tabular}




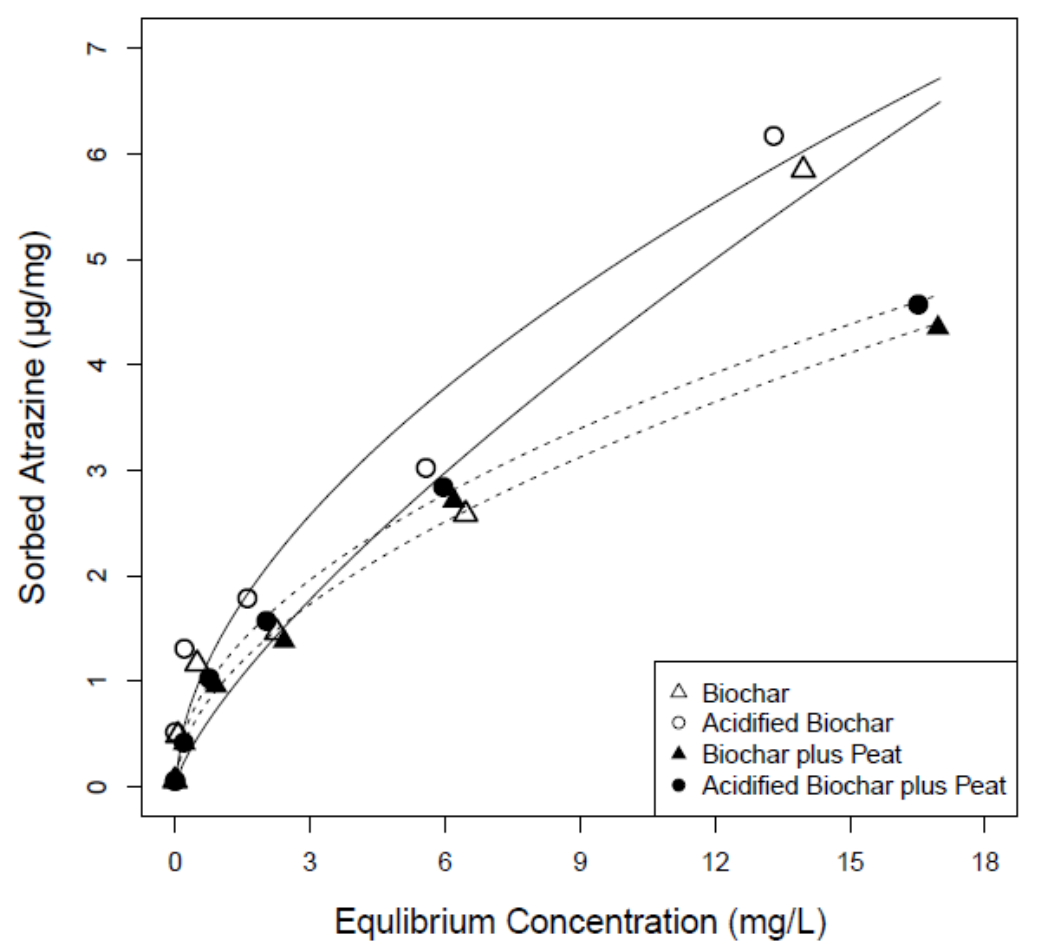

Figure 5. Sorption isotherms for biochar (hollow triangle), acidified biochar (hollow circle), biochar plus peat (triangle), and acidified biochar plus peat (circle) showing sorbed atrazine in $\mu \mathrm{g} / \mathrm{mg}$ versus equilibrium concentration $(\mathrm{mg} / \mathrm{L})$. Plotted lines are derived from the Freundlich model with dashed lines for isotherms with peat and solid lines for isotherms without peat (model values in Table 5).

We note that while the data have a high degree of correlation with the model predictions (see $\mathrm{R}^{2}$ values in Table 5), close examination of Figure 5 shows that there may be evidence for dual-mode sorption behavior in the isotherms without peat. Specifically, data appears to follow a non-linear trend at low concentrations, transitioning to an apparently linear trend at higher concentrations. Previous studies have shown similar sorption patterns for organic compounds and have attributed this phenomenon to adsorption-dominated sorption at low equilibrium concentrations and partitioning-dominated sorption at high equilibrium concentrations (Xing et al., 1996; Chiou et al., 1998; Chen et al., 2008). More work would be needed to determine if this 
dual-sorption phenomenon is occurring. The increases in sorption capacity for the acidified biochar relative to the untreated biochar are consistent with our field results; i.e., the lower atrazine concentrations in the acidified biochar plot samples relative to the untreated biochar plot samples.

Both the atrazine concentration in field samples and the isotherm analysis indicate that the acidified biochar treatment may sorb atrazine more effectively than the regular biochar. The exact mechanism for this enhanced adsorption is still unknown, but one possibility is that biochar surface impurities that could reduce microporosity were removed during the acidification step. Jia et al., 2008, used a scanning electron micrograph to show that some char surfaces were covered in tar-like deposits. Another study by Lozano-Castello et al., 2001, found that washing pyrolyzed anthracite in $\mathrm{HCl}$ reduces ash content from $7 \% \mathrm{wt}$ to $<1 \% \mathrm{wt}$ and increases micropore volume. It is possible that the biochar acidification step removed surface impurities and therefore exposed more micropores to atrazine sorption. Further work is needed to determine the exact sorption mechanisms.

\section{Peat Moss Effect}

The field data show that average leachate concentration for the peat plus biochar treatments is similar to the control treatments, and apparently higher than the biochar treatments. Peat moss alone is not statistically different than the control group, indicating that it's affinity for sorbing atrazine is not significantly higher than the native soil. The soil extraction results show that adding peat to biochar-amended soil will significantly reduce the amount of atrazine retained in the soil profile. The leachate and extraction results show that the peat plus biochar plots had both lower atrazine retention in the soil surface and higher atrazine concentration in leachate 
compared to control. Additionally, the isotherm results (Figure 5) show that adding peat to biochar increases the amount of atrazine in solution.

These results are consistent with the hypothesis that the peat moss is impeding biochar's ability to sorb atrazine. This hypothesis is supported by previous studies showing that the presence of organic matter in soils can decrease biochar sorption of organic compounds (Pignatello et al., 2006; Qiu et al., 2009). Pignatello et al. found evidence that humic substances reduce organic compound sorption to char by either blocking access to char micropores or competing for char surface adsorption sites. Qiu et al. also found evidence that dissolved organic matter blocks biochar micropores and decreases pesticide sorption. Our results are consistent with either organic-matter induced pore-blocking or sorption competition between organic matter and atrazine. We therefore assume that the effects of biochar on atrazine leaching will be less pronounced in soils with naturally high organic matter contents. 


\section{CHAPTER 4}

\section{CONCLUSIONS}

We conclude that biochar use as a soil amendment may reduce atrazine leaching. This effect appears to depend significantly on heterogeneous soil pore structure. In homogenized soil we see a reduction in atrazine leaching with biochar use. Adding complexity in the soil pore structure increases variation and reduces the difference in atrazine leaching between biochar and control experiments. Anomalously large leaching events appear to occur irrespective of soil treatment, indicating that localized soil structure heterogeneities could play a dominant role in causing rare, large leaching events. Even with soil heterogeneities, it appears that biochar acidified prior to soil application can significantly reduce atrazine concentrations in leachate. More work is needed to quantify the amount of atrazine leached from biochar-amended fields to determine if the reduced leaching is significant enough to reduce groundwater contamination levels. Continuing to gather water samples in future years from these plots will provide important information on how biochar aging affects atrazine leaching, and whether trends observed in the first year will be maintained in subsequent years. 


\section{APPENDIX A - Bentonite Clay Isotherms}

Upon collecting and filtering the samples, we noted that many of the samples contained a clay-like substance that we assumed to be the bentonite clay used to cap the wells. Upon closer inspection of the wells, we determined that some of the bentonite from the surface cap had migrated downwards through the gravel surrounding the wells, and had potentially entered the water samples. Concerned about bentonite's potential ability to sorb atrazine and interfere with our samples, we conducted a 24 hour bentonite/atrazine sorption isotherm test. Bentonite isotherms were conducted in duplicate using 0.5 grams of dry bentonite powder mixed with 25 $\mathrm{mL}$ of varying concentrations of atrazine $(10,50,100,300$, and $1,000 \mu \mathrm{g} / \mathrm{L}$ atrazine in $0.01 \mathrm{M}$ $\mathrm{CaCl} 2$ ). Samples were shaken horizontally for 24 hours, centrifuged, and filtered to $0.45 \mu \mathrm{m}$.

The results of this test show an essentially linear isotherm over relevant atrazine concentrations (Figure 6). Based on these data we assume that the presence of bentonite has some ability to sorb atrazine, potentially changing the atrazine concentrations in our samples. We approximated the quantity of clay in each sample, and grouped our samples into low to high categories. Water samples with very low clay amounts had lower atrazine concentrations than samples with either a medium or high amount of clay $(\mathrm{p}<0.0001$ and $\mathrm{p}=0.0027$, respectively). This result indicates that even though bentonite is capable of sorbing some atrazine, samples with increased bentonite still had more atrazine than those with low concentration. The presence of bentonite might therefore be indicative of soil conditions that increase transport of material from the soil surface to the subsurface. Specifically, this transport could occur through soil macropores, or potentially through the gravel casing around the well. We used linear regression 
to model atrazine concentration as a function of clay content category and soil treatment. When accounting for clay in the samples and removing the outliers, the soil treatment still had a significant effect on leachate atrazine concentrations $(\mathrm{p}=0.0138)$. We therefore assume that while the presence of clay may be indicative of local transport processes, our results regarding treatment effect on atrazine leaching are still valid. Prior to the onset of the winter season, the remaining bentonite caps were removed and replaced with native soil to limit future bentonite migration into samples.

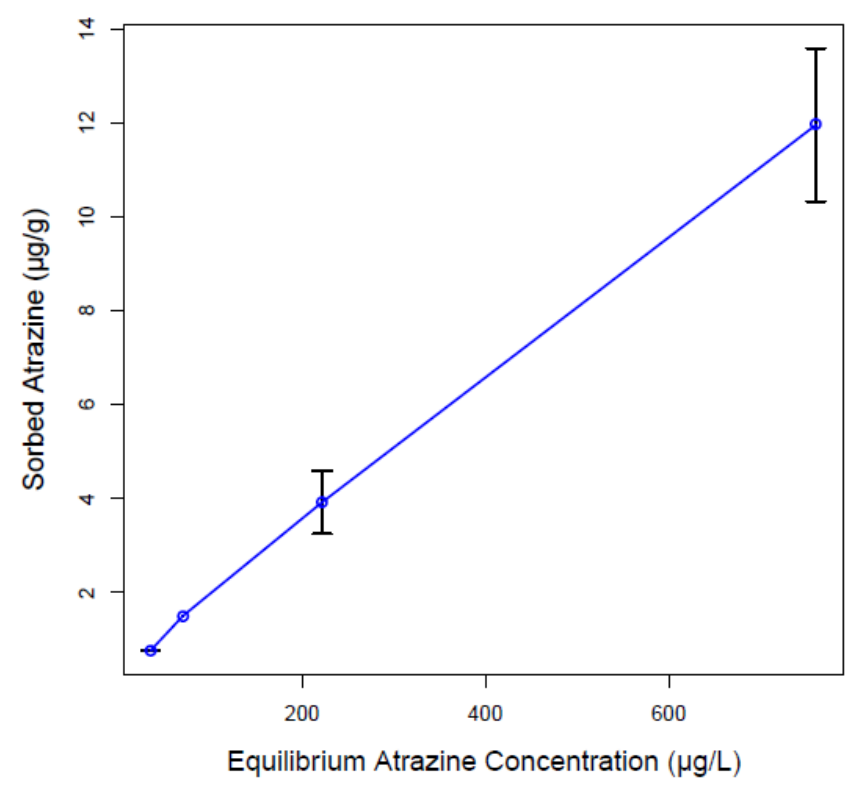

Figure 6. Bentonite and atrazine sorption isotherm. Horizontal axis represents equilibrium atrazine concentration in $\mu \mathrm{g} / \mathrm{L}$ and vertical axis represents amount of atrazine sorbed to bentonite in $\mu \mathrm{g} / \mathrm{g}$. Error bars are standard deviation from two samples. 


\section{APPENDIX B - Data}

Table 6 - Data from Homogenized Soil Column Experiment

\begin{tabular}{|c|c|c|c|c|}
\hline Column & Treatment & $\begin{array}{l}\text { Sample } \\
\text { Time } \\
\text { (hours) }\end{array}$ & $\begin{array}{l}\text { Atrazine } \\
\text { Concentration } \\
(\mu \mathrm{g} / \mathrm{L})\end{array}$ & $\begin{array}{l}\text { Cumulative } \\
\text { Leached } \\
\text { Water } \\
\text { Volume (L) }\end{array}$ \\
\hline 1 & Control & 0.75 & 79.13 & 0.8 \\
\hline 1 & Control & 1.58 & 127.86 & 1.5 \\
\hline 1 & Control & 2.67 & 125.27 & 2.4 \\
\hline 1 & Control & 3.58 & 93.38 & 3.2 \\
\hline 1 & Control & 4.75 & 81.27 & 4.2 \\
\hline 1 & Control & 7.50 & 33.93 & 6.4 \\
\hline 2 & Control & 0.75 & 7.66 & 0.6 \\
\hline 2 & Control & 1.58 & 92.91 & 1.1 \\
\hline 2 & Control & 2.67 & 133.04 & 1.8 \\
\hline 2 & Control & 3.58 & 127.35 & 2.4 \\
\hline 2 & Control & 4.75 & 99.09 & 3.2 \\
\hline 2 & Control & 7.50 & 63.24 & 5.0 \\
\hline 3 & Biochar & 0.75 & 44.47 & 0.9 \\
\hline 3 & Biochar & 1.58 & 102.58 & 1.6 \\
\hline 3 & Biochar & 2.67 & 75.39 & 2.4 \\
\hline 3 & Biochar & 3.58 & 64.13 & 3.1 \\
\hline 3 & Biochar & 4.75 & 61.68 & 4.1 \\
\hline 3 & Biochar & 7.50 & 19.96 & 6.3 \\
\hline 4 & Control & 0.75 & 106.20 & 1.0 \\
\hline 4 & Control & 1.58 & 144.46 & 1.6 \\
\hline 4 & Control & 2.67 & 163.71 & 2.4 \\
\hline 4 & Control & 3.58 & 101.17 & 3.1 \\
\hline 4 & Control & 4.75 & 156.19 & 4.0 \\
\hline 4 & Control & 7.50 & 29.56 & 6.3 \\
\hline 5 & Biochar & 0.75 & 32.73 & 1.0 \\
\hline 5 & Biochar & 1.58 & 59.81 & 1.5 \\
\hline 5 & Biochar & 2.67 & 71.70 & 2.3 \\
\hline 5 & Biochar & 3.58 & 46.46 & 3.1 \\
\hline 5 & Biochar & 4.75 & 34.26 & 4.1 \\
\hline 5 & Biochar & 7.50 & 18.80 & 6.3 \\
\hline 6 & Biochar & 0.75 & 19.73 & 0.7 \\
\hline 6 & Biochar & 1.58 & 52.35 & 1.3 \\
\hline 6 & Biochar & 2.67 & 87.68 & 2.0 \\
\hline
\end{tabular}




\begin{tabular}{|lllll|}
6 & Biochar & 3.58 & 52.21 & 2.8 \\
6 & Biochar & 4.75 & 46.44 & 3.7 \\
6 & Biochar & 7.50 & 23.52 & 5.8 \\
\hline
\end{tabular}

Table 7 - Data from Undisturbed Soil Column Experiment

\begin{tabular}{|c|c|c|c|c|}
\hline Column & Treatment & $\begin{array}{l}\text { Sample } \\
\text { Time } \\
\text { (hours) }\end{array}$ & $\begin{array}{l}\text { Atrazine } \\
\text { Concentration } \\
(\mu \mathrm{g} / \mathrm{L})\end{array}$ & $\begin{array}{l}\text { Cumulative } \\
\text { Leached } \\
\text { Water } \\
\text { Volume } \\
\text { (L) } \\
\end{array}$ \\
\hline 1 & Control & 0 & 447.62 & 0.00 \\
\hline 1 & Control & 1 & 371.34 & 0.96 \\
\hline 1 & Control & 2.5 & 310.02 & 2.40 \\
\hline 1 & Control & 4 & 231.28 & 3.84 \\
\hline 1 & Control & 5.5 & 179.51 & 5.28 \\
\hline 1 & Control & 7 & 126.65 & 6.72 \\
\hline 2 & Biochar & 0 & 39.78 & 0.00 \\
\hline 2 & Biochar & 1 & 157.46 & 0.96 \\
\hline 2 & Biochar & 2.5 & 142.55 & 2.40 \\
\hline 2 & Biochar & 4 & 141.98 & 3.84 \\
\hline 2 & Biochar & 5.5 & 121.69 & 5.28 \\
\hline 2 & Biochar & 7 & 95.99 & 6.72 \\
\hline 3 & Control & 0 & 106.73 & 0.00 \\
\hline 3 & Control & 1 & 276.39 & 0.96 \\
\hline 3 & Control & 2.5 & 302.30 & 2.40 \\
\hline 3 & Control & 4 & 253.80 & 3.84 \\
\hline 3 & Control & 5.5 & 246.49 & 5.28 \\
\hline 3 & Control & 7 & 199.74 & 6.72 \\
\hline 4 & Biochar & 0 & 71.84 & 0.00 \\
\hline 4 & Biochar & 1 & 243.66 & 0.96 \\
\hline 4 & Biochar & 2.5 & 283.01 & 2.40 \\
\hline 4 & Biochar & 4 & 234.56 & 3.84 \\
\hline 4 & Biochar & 5.5 & 189.54 & 5.28 \\
\hline 4 & Biochar & 7 & 176.40 & 6.72 \\
\hline 5 & Control & 0 & 60.52 & 0.00 \\
\hline 5 & Control & 1 & 115.15 & 0.96 \\
\hline 5 & Control & 2.5 & 198.22 & 2.40 \\
\hline 5 & Control & 4 & 202.52 & 3.84 \\
\hline 5 & Control & 5.5 & 192.28 & 5.28 \\
\hline 5 & Control & 7 & 183.08 & 6.72 \\
\hline 6 & Biochar & 0 & 25.10 & 0.00 \\
\hline 6 & Biochar & 1 & 87.25 & 0.96 \\
\hline 6 & Biochar & 2.5 & 162.89 & 2.40 \\
\hline
\end{tabular}




\begin{tabular}{|llrrr|}
6 & Biochar & 4 & 171.53 & 3.84 \\
6 & Biochar & 5.5 & 159.54 & 5.28 \\
6 & Biochar & 7 & 155.49 & 6.72 \\
\hline
\end{tabular}

Table 8 - Atrazine Concentrations in Groundwater Samples Collected From Field Plots

\begin{tabular}{|c|c|c|c|c|c|}
\hline Block & Treatment & $\begin{array}{l}\text { Well } \\
\text { ID }\end{array}$ & $\begin{array}{l}\text { Atrazine } \\
\text { Concentration } \\
(\mu \mathrm{g} / \mathrm{L})\end{array}$ & $\begin{array}{l}\text { Water } \\
\text { Height } \\
\text { Within } \\
\text { Well }(\mathrm{cm})\end{array}$ & $\begin{array}{l}\text { Approximate } \\
\text { Clay } \\
\text { Concentration } \\
\text { Within Water } \\
\text { Sample } \\
(\mathrm{mg} / \mathrm{mL})\end{array}$ \\
\hline 1 & Acidified Biochar & A1 & 25.26 & 2.1 & 0 \\
\hline 1 & Acidified Biochar & A2 & 15.09 & 0.8 & 0 \\
\hline 1 & Acidified Biochar & A3 & 44.97 & 0.7 & 0 \\
\hline 1 & Acidified Biochar & A4 & 12.58 & 0.1 & 0 \\
\hline 1 & Control & B1 & 66.05 & 0.3 & 0 \\
\hline 1 & Control & B2 & 35.45 & 1.6 & 0 \\
\hline 1 & Control & B3 & 56.17 & 0.4 & 0 \\
\hline 1 & Control & B4 & 26.37 & 0.5 & 0 \\
\hline 1 & Biochar & $\mathrm{C} 1$ & 90.08 & 1.4 & 3.36 \\
\hline 1 & Biochar & $\mathrm{C} 2$ & 12.26 & 0.9 & 0 \\
\hline 1 & Biochar & $\mathrm{C} 3$ & 50.11 & 0.6 & 0 \\
\hline 1 & Biochar & $\mathrm{C} 4$ & 35.07 & 0.2 & 0 \\
\hline 1 & Peat & D1 & 105.51 & 1.1 & 6.45 \\
\hline 1 & Peat & $\mathrm{D} 2$ & 140.77 & - & 13.85 \\
\hline 1 & Peat & D3 & 99.12 & 1.4 & 2 \\
\hline 1 & Peat & D4 & 85.10 & 1.1 & 0 \\
\hline 1 & Peat/Biochar & E1 & 108.46 & 0.5 & 0 \\
\hline 1 & Peat/Biochar & E2 & 48.39 & 0.0 & 0 \\
\hline 1 & Peat/Biochar & E3 & - & 0.3 & 0 \\
\hline 1 & Peat/Biochar & E4 & - & - & - \\
\hline 2 & Biochar & $\mathrm{F} 1$ & 37.91 & 0.4 & 0 \\
\hline 2 & Biochar & F2 & 44.34 & 0.3 & 0 \\
\hline 2 & Biochar & F3 & 74.40 & 0.6 & 0 \\
\hline 2 & Biochar & F4 & 31.04 & 0.8 & 0 \\
\hline 2 & Peat & G1 & 29.55 & 0.5 & 0 \\
\hline 2 & Peat & $\mathrm{G} 2$ & 103.59 & 2.3 & 0 \\
\hline 2 & Peat & G3 & 13.23 & 1.8 & 0 \\
\hline 2 & Peat & G4 & 65.59 & 0.4 & 12.15 \\
\hline 2 & Acidified Biochar & H1 & 17.37 & 0.7 & 0 \\
\hline 2 & Acidified Biochar & $\mathrm{H} 2$ & 73.07 & 0.9 & 3.9 \\
\hline 2 & Acidified Biochar & H3 & 34.94 & 0.0 & 0 \\
\hline
\end{tabular}


Table 8 - Continued

\begin{tabular}{|c|c|c|c|c|c|}
\hline 2 & Acidified Biochar & $\mathrm{H} 4$ & 39.66 & 0.4 & 0 \\
\hline 2 & Peat/Biochar & $\mathrm{I} 1$ & 68.51 & 1.5 & 5.85 \\
\hline 2 & Peat/Biochar & $\mathrm{I} 2$ & 84.58 & 1.0 & 0 \\
\hline 2 & Peat/Biochar & $\mathrm{I} 3$ & 63.58 & 1.0 & 2.95 \\
\hline 2 & Peat/Biochar & I4 & 113.37 & 0.6 & 5.15 \\
\hline 2 & Control & $\mathrm{J} 1$ & 105.42 & 0.1 & 0 \\
\hline 2 & Control & $\mathrm{J} 2$ & 133.33 & 0.1 & 26.5 \\
\hline 2 & Control & $\mathrm{J} 3$ & 155.55 & 1.8 & 5.45 \\
\hline 2 & Control & $\mathrm{J} 4$ & 73.46 & 0.7 & 10.05 \\
\hline 3 & Peat/Biochar & $\mathrm{K} 1$ & - & - & - \\
\hline 3 & Peat/Biochar & $\mathrm{K} 2$ & - & - & - \\
\hline 3 & Peat/Biochar & K3 & 22.76 & 1.5 & 1.95 \\
\hline 3 & Peat/Biochar & $\mathrm{K} 4$ & 113.79 & 0.9 & 8 \\
\hline 3 & Acidified Biochar & L1 & 19.35 & 0.0 & 0 \\
\hline 3 & Acidified Biochar & $\mathrm{L} 2$ & - & - & - \\
\hline 3 & Acidified Biochar & L3 & 25.29 & 0.9 & 0 \\
\hline 3 & Acidified Biochar & L4 & - & - & - \\
\hline 3 & Peat & M1 & 27.86 & 0.3 & 0 \\
\hline 3 & Peat & M2 & 114.55 & 0.8 & 3.95 \\
\hline 3 & Peat & M3 & - & - & - \\
\hline 3 & Peat & M4 & - & - & - \\
\hline 3 & Control & $\mathrm{N} 1$ & 101.55 & 0.1 & 13.35 \\
\hline 3 & Control & $\mathrm{N} 2$ & - & - & - \\
\hline 3 & Control & N3 & - & - & - \\
\hline 3 & Control & $\mathrm{N} 4$ & 119.90 & 0.4 & 19.55 \\
\hline 3 & Biochar & $\mathrm{O} 1$ & 228.39 & 0.1 & 18.9 \\
\hline 3 & Biochar & $\mathrm{O} 2$ & 67.40 & 0.3 & 15.1 \\
\hline 3 & Biochar & $\mathrm{O} 3$ & 222.33 & 0.5 & 15.25 \\
\hline 3 & Biochar & $\mathrm{O} 4$ & - & - & - \\
\hline 4 & Control & $\mathrm{P} 1$ & 80.65 & 0.8 & 3.35 \\
\hline 4 & Control & $\mathrm{P} 2$ & 81.04 & 1.3 & 5.3 \\
\hline 4 & Control & P3 & 77.70 & 0.6 & 1.1 \\
\hline 4 & Control & $\mathrm{P} 4$ & - & 0.6 & 8.55 \\
\hline 4 & Biochar & Q1 & 45.10 & 0.8 & 0 \\
\hline 4 & Biochar & $\mathrm{Q} 2$ & 52.67 & 0.7 & 0 \\
\hline 4 & Biochar & Q3 & 41.07 & 0.3 & 31.2 \\
\hline 4 & Biochar & Q4 & - & - & - \\
\hline 4 & Peat/Biochar & $\mathrm{R} 1$ & 139.92 & 0.5 & 21.3 \\
\hline 4 & Peat/Biochar & R2 & - & - & - \\
\hline 4 & Peat/Biochar & R3 & - & - & - \\
\hline 4 & Peat/Biochar & $\mathrm{R} 4$ & - & - & - \\
\hline 4 & Acidified Biochar & $\mathrm{S} 1$ & 42.58 & 0.9 & 4.5 \\
\hline 4 & Acidified Biochar & $\mathrm{S} 2$ & 37.00 & 0.3 & 0 \\
\hline
\end{tabular}


Table 8 - Continued

\begin{tabular}{|c|c|c|c|c|c|}
\hline 4 & Acidified Biochar & S3 & 58.52 & 0.2 & 0 \\
\hline 4 & Acidified Biochar & $\mathrm{S} 4$ & 68.92 & 0.9 & 7.5 \\
\hline 4 & Peat & $\mathrm{T} 1$ & 74.83 & 1.0 & 3.45 \\
\hline 4 & Peat & $\mathrm{T} 2$ & 52.31 & 0.8 & 7.8 \\
\hline 4 & Peat & $\mathrm{T} 3$ & 114.93 & 1.3 & 5.55 \\
\hline 4 & Peat & $\mathrm{T} 4$ & 6.69 & 0.0 & 0 \\
\hline 5 & Peat & U1 & 100.91 & 0.4 & 15 \\
\hline 5 & Peat & $\mathrm{U} 2$ & 133.42 & 0.5 & 9.15 \\
\hline 5 & Peat & U3 & 66.03 & 0.3 & 9 \\
\hline 5 & Peat & U4 & 94.97 & 1.3 & 5 \\
\hline 5 & Peat/Biochar & V1 & 100.51 & 0.1 & 38.2 \\
\hline 5 & Peat/Biochar & $\mathrm{V} 2$ & 108.92 & 0.1 & 0 \\
\hline 5 & Peat/Biochar & V3 & 78.11 & 0.2 & 21.25 \\
\hline 5 & Peat/Biochar & V4 & 152.20 & 0.2 & 18 \\
\hline 5 & Biochar & W1 & - & - & - \\
\hline 5 & Biochar & W2 & - & - & - \\
\hline 5 & Biochar & W3 & 94.24 & 0.3 & 20 \\
\hline 5 & Biochar & W4 & - & 0.2 & 19.58 \\
\hline 5 & Acidified Biochar & $\mathrm{X} 1$ & - & - & - \\
\hline 5 & Acidified Biochar & $\mathrm{X} 2$ & - & 0.3 & 18.9 \\
\hline 5 & Acidified Biochar & $\mathrm{X} 3$ & - & 0.2 & 4.75 \\
\hline 5 & Acidified Biochar & $\mathrm{X} 4$ & - & - & - \\
\hline 5 & Control & Y1 & - & 0.1 & 21.6 \\
\hline 5 & Control & Y2 & - & - & - \\
\hline 5 & Control & Y3 & - & - & - \\
\hline 5 & Control & Y4 & - & 0.0 & 9.55 \\
\hline
\end{tabular}

Table 9 - Atrazine Extracted from Field Soil Samples

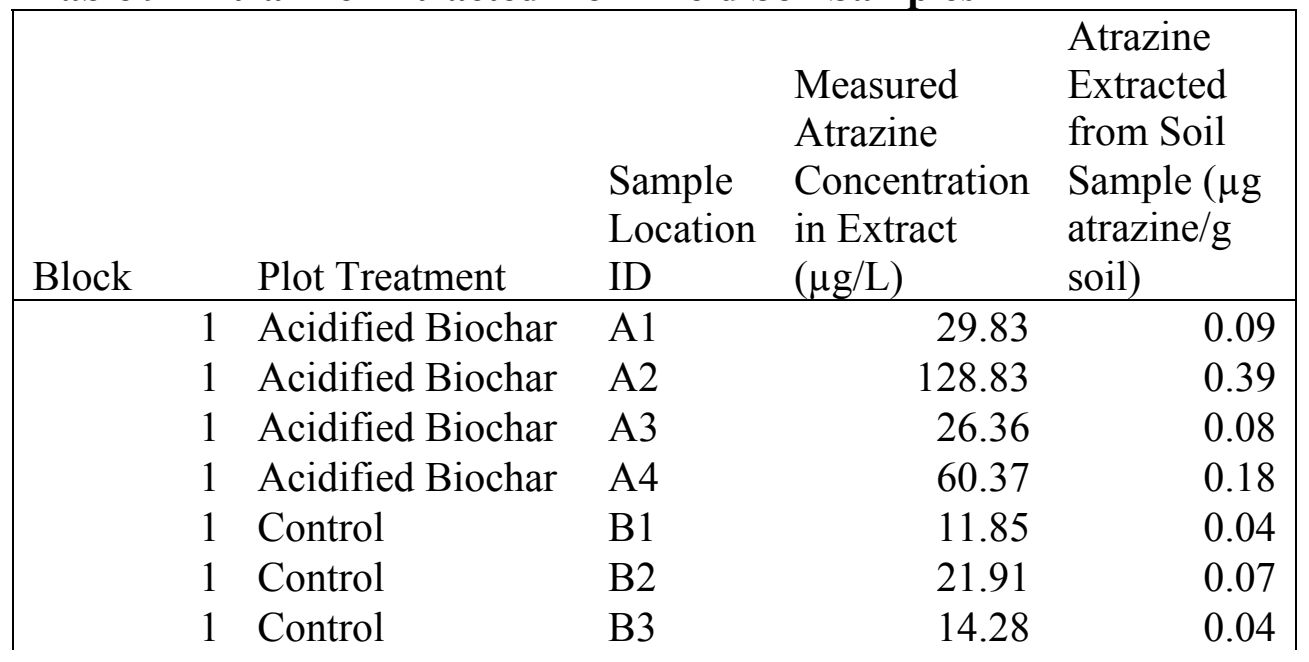


Table 9 - Continued

\begin{tabular}{|c|c|c|c|c|}
\hline 1 & Control & B4 & 19.31 & 0.06 \\
\hline 1 & Biochar & $\mathrm{C} 1$ & 146.03 & 0.44 \\
\hline 1 & Biochar & $\mathrm{C} 2$ & 71.94 & 0.22 \\
\hline 1 & Biochar & $\mathrm{C} 3$ & 13.34 & 0.04 \\
\hline 1 & Biochar & $\mathrm{C} 4$ & 96.06 & 0.29 \\
\hline 1 & Peat & D1 & 0.00 & 0.00 \\
\hline 1 & Peat & D2 & 29.65 & 0.09 \\
\hline 1 & Peat & D3 & 15.49 & 0.05 \\
\hline 1 & Peat & D4 & 10.16 & 0.03 \\
\hline 1 & Peat/Biochar & E1 & 60.21 & 0.18 \\
\hline 1 & Peat/Biochar & E2 & 113.94 & 0.34 \\
\hline 1 & Peat/Biochar & E3 & 25.13 & 0.08 \\
\hline 1 & Peat/Biochar & E4 & 52.21 & 0.16 \\
\hline 2 & Biochar & $\mathrm{F} 1$ & 104.08 & 0.31 \\
\hline 2 & Biochar & $\mathrm{F} 2$ & 112.65 & 0.34 \\
\hline 2 & Biochar & F3 & 203.98 & 0.61 \\
\hline 2 & Biochar & $\mathrm{F} 4$ & 162.33 & 0.49 \\
\hline 2 & Peat & G1 & 14.93 & 0.04 \\
\hline 2 & Peat & $\mathrm{G} 2$ & 8.46 & 0.03 \\
\hline 2 & Peat & G3 & 14.32 & 0.04 \\
\hline 2 & Peat & G4 & 5.64 & 0.02 \\
\hline 2 & Acidified Biochar & $\mathrm{H} 1$ & 87.76 & 0.26 \\
\hline 2 & Acidified Biochar & $\mathrm{H} 2$ & 145.65 & 0.44 \\
\hline 2 & Acidified Biochar & $\mathrm{H} 3$ & 66.56 & 0.20 \\
\hline 2 & Acidified Biochar & $\mathrm{H} 4$ & 168.70 & 0.51 \\
\hline 2 & Peat/Biochar & I1 & 16.69 & 0.05 \\
\hline 2 & Peat/Biochar & $\mathrm{I} 2$ & 5.08 & 0.02 \\
\hline 2 & Peat/Biochar & $\mathrm{I} 3$ & 116.52 & 0.35 \\
\hline 2 & Peat/Biochar & I4 & 18.03 & 0.05 \\
\hline 2 & Control & $\mathrm{J} 1$ & 12.70 & 0.04 \\
\hline 2 & Control & $\mathrm{J} 2$ & 38.67 & 0.12 \\
\hline 2 & Control & $\mathrm{J} 3$ & 27.32 & 0.08 \\
\hline 2 & Control & $\mathrm{J} 4$ & 18.18 & 0.05 \\
\hline 3 & Peat/Biochar & $\mathrm{K} 1$ & 0.07 & 0.00 \\
\hline 3 & Peat/Biochar & $\mathrm{K} 2$ & 8.40 & 0.03 \\
\hline 3 & Peat/Biochar & $\mathrm{K} 3$ & 24.94 & 0.07 \\
\hline 3 & Peat/Biochar & $\mathrm{K} 4$ & 20.75 & 0.06 \\
\hline 3 & Acidified Biochar & L1 & 337.77 & 1.01 \\
\hline 3 & Acidified Biochar & $\mathrm{L} 2$ & 55.49 & 0.17 \\
\hline 3 & Acidified Biochar & L3 & 229.25 & 0.69 \\
\hline 3 & Acidified Biochar & $\mathrm{L} 4$ & 56.42 & 0.17 \\
\hline 3 & Peat & M1 & 39.60 & 0.12 \\
\hline 3 & Peat & M2 & 75.48 & 0.23 \\
\hline
\end{tabular}


Table 9 - Continued

\begin{tabular}{|c|c|c|c|c|}
\hline 3 & Peat & M3 & 7.13 & 0.02 \\
\hline 3 & Peat & M4 & 0.07 & 0.00 \\
\hline 3 & Control & N1 & 11.93 & 0.04 \\
\hline 3 & Control & N2 & 19.32 & 0.06 \\
\hline 3 & Control & N3 & 28.55 & 0.09 \\
\hline 3 & Control & N4 & 13.73 & 0.04 \\
\hline 3 & Biochar & $\mathrm{O} 1$ & 39.02 & 0.12 \\
\hline 3 & Biochar & $\mathrm{O} 2$ & 48.71 & 0.15 \\
\hline 3 & Biochar & $\mathrm{O} 3$ & 180.72 & 0.54 \\
\hline 3 & Biochar & $\mathrm{O} 4$ & 141.80 & 0.43 \\
\hline 4 & Control & $\mathrm{P} 1$ & 19.67 & 0.06 \\
\hline 4 & Control & $\mathrm{P} 2$ & 6.66 & 0.02 \\
\hline 4 & Control & P3 & 20.44 & 0.06 \\
\hline 4 & Control & P4 & 6.70 & 0.02 \\
\hline 4 & Biochar & Q1 & 237.60 & 0.71 \\
\hline 4 & Biochar & Q2 & 100.08 & 0.30 \\
\hline 4 & Biochar & Q3 & 11.22 & 0.03 \\
\hline 4 & Biochar & Q4 & 129.33 & 0.39 \\
\hline 4 & Peat/Biochar & $\mathrm{R} 1$ & 44.71 & 0.13 \\
\hline 4 & Peat/Biochar & $\mathrm{R} 2$ & 11.18 & 0.03 \\
\hline 4 & Peat/Biochar & R3 & 59.06 & 0.18 \\
\hline 4 & Peat/Biochar & $\mathrm{R} 4$ & 18.19 & 0.05 \\
\hline 4 & Acidified Biochar & $\mathrm{S} 1$ & 55.00 & 0.16 \\
\hline 4 & Acidified Biochar & $\mathrm{S} 2$ & 67.69 & 0.20 \\
\hline 4 & Acidified Biochar & $\mathrm{S} 3$ & 152.30 & 0.46 \\
\hline 4 & Acidified Biochar & $\mathrm{S} 4$ & 134.86 & 0.40 \\
\hline 4 & Peat & $\mathrm{T} 1$ & 0.00 & 0.00 \\
\hline 4 & Peat & $\mathrm{T} 2$ & 39.70 & 0.12 \\
\hline 4 & Peat & $\mathrm{T} 3$ & 0.00 & 0.00 \\
\hline 4 & Peat & $\mathrm{T} 4$ & 0.00 & 0.00 \\
\hline 5 & Peat & U1 & 6.68 & 0.02 \\
\hline 5 & Peat & U2 & 5.85 & 0.02 \\
\hline 5 & Peat & U3 & 6.47 & 0.02 \\
\hline 5 & Peat & U4 & 8.52 & 0.03 \\
\hline 5 & Peat/Biochar & V1 & 0.00 & 0.00 \\
\hline 5 & Peat/Biochar & $\mathrm{V} 2$ & 60.82 & 0.18 \\
\hline 5 & Peat/Biochar & V3 & 77.64 & 0.23 \\
\hline 5 & Peat/Biochar & V4 & 12.42 & 0.04 \\
\hline 5 & Biochar & W1 & 31.55 & 0.09 \\
\hline 5 & Biochar & $\mathrm{W} 2$ & 58.53 & 0.18 \\
\hline 5 & Biochar & W3 & 193.26 & 0.58 \\
\hline 5 & Biochar & W4 & 20.18 & 0.06 \\
\hline 5 & Acidified Biochar & $\mathrm{X} 1$ & 192.91 & 0.58 \\
\hline
\end{tabular}


Table 9 - Continued

\begin{tabular}{|lllrl|}
\hline 5 & Acidified Biochar & $\mathrm{X} 2$ & 84.82 & 0.25 \\
5 & Acidified Biochar & $\mathrm{X} 3$ & 122.97 & 0.37 \\
5 & Acidified Biochar & $\mathrm{X} 4$ & 58.77 & 0.18 \\
5 & Control & $\mathrm{Y} 1$ & 9.14 & 0.03 \\
5 & Control & $\mathrm{Y} 2$ & 0.00 & 0.00 \\
5 & Control & $\mathrm{Y} 3$ & 6.47 & 0.02 \\
5 & Control & $\mathrm{Y} 4$ & 0.00 & 0.00 \\
\hline
\end{tabular}

Table 10 - Data from atrazine/biochar isotherm study.

\begin{tabular}{|c|c|c|c|c|}
\hline \multirow[b]{2}{*}{$\begin{array}{l}\text { Initial } \\
\text { Atrazine } \\
\text { Concentration } \\
(\mu \mathrm{g} / \mathrm{L})\end{array}$} & \multicolumn{4}{|c|}{$\begin{array}{l}\text { Equilibrium Atrazine Concentration }(\mu \mathrm{g} / \mathrm{L}) \\
\text { for: }\end{array}$} \\
\hline & $\begin{array}{l}\text { Regular } \\
\text { Biochar }\end{array}$ & $\begin{array}{l}\text { Acidified } \\
\text { Biochar }\end{array}$ & $\begin{array}{l}\text { Regular } \\
\text { Biochar } \\
+ \text { Peat }\end{array}$ & $\begin{array}{l}\text { Acidified } \\
\text { Biochar } \\
+ \text { Peat }\end{array}$ \\
\hline 100 & 0.00 & 0.00 & 11.09 & 7.36 \\
\hline 100 & 0.00 & 0.00 & 8.98 & 6.69 \\
\hline 100 & 0.00 & 0.00 & 13.52 & 10.37 \\
\hline 1,000 & 62.58 & 16.00 & 193.07 & 141.59 \\
\hline 1,000 & 57.22 & 5.62 & 230.51 & 210.59 \\
\hline 1,000 & 78.56 & 12.51 & 211.32 & 225.81 \\
\hline 2,000 & 410.84 & 185.90 & 1167.32 & 773.41 \\
\hline 2,000 & 588.12 & 218.30 & 676.35 & 694.31 \\
\hline 2,000 & 475.23 & 217.58 & 893.96 & 822.32 \\
\hline 5,000 & 2410.27 & 1652.56 & 2488.92 & 2109.16 \\
\hline 5,000 & 2181.50 & 1686.93 & 2441.82 & 1893.79 \\
\hline 5,000 & 2190.34 & 1503.01 & 2344.29 & 2092.17 \\
\hline 10,000 & 6506.53 & 5422.63 & 5713.40 & 6027.02 \\
\hline 10,000 & 6472.77 & 5591.32 & 6088.17 & 5819.79 \\
\hline 10,000 & 6399.09 & 5734.90 & 6790.77 & 6023.52 \\
\hline 20,000 & 13709.18 & 13559.41 & 18537.76 & 15834.05 \\
\hline 20,000 & 14298.56 & 13592.66 & 16718.17 & 17258.34 \\
\hline 20,000 & 13876.72 & 12752.85 & 15605.01 & 16451.97 \\
\hline
\end{tabular}


Table 11 - Results from atrazine/bentonite isotherm study

\begin{tabular}{|c|c|}
\hline $\begin{array}{l}\text { Initial } \\
\text { Atrazine } \\
\text { Concentration } \\
(\mu \mathrm{g} / \mathrm{L})\end{array}$ & $\begin{array}{l}\text { Equilibrium } \\
\text { Atrazine } \\
\text { Concentration } \\
(\mu \mathrm{g} / \mathrm{L})\end{array}$ \\
\hline 0 & 0.83 \\
\hline 0 & 0.48 \\
\hline 50 & 34.47 \\
\hline 50 & 34.88 \\
\hline 100 & 69.99 \\
\hline 100 & 69.87 \\
\hline 300 & 212.10 \\
\hline 300 & 231.06 \\
\hline 1,000 & 737.67 \\
\hline 1,000 & 783.76 \\
\hline
\end{tabular}




\section{REFERENCES}

Abiven, S., Hengartner, P., Schneider, M. P. W., Singh, N., \& Schmidt, M. W. I. (2011). Pyrogenic carbon soluble fraction is larger and more aromatic in aged charcoal than in fresh charcoal. Soil Biology and Biochemistry, 43(7), 1615-1617.

Accardi-Dey, A., \& Gschwend, P. M. (2003). Reinterpreting literature sorption data considering both absorption into organic carbon and adsorption onto black carbon. Environmental Science and Technology, 37(1), 99-106.

Akhtar, M. S., Steenhuis, T. S., Richards, B. K., \& McBride, M. B. (2003). Chloride and lithium transport in large arrays of undisturbed silt loam and sandy loam soil columns. Vadose Zone Journal, 2(4), 715-727.

Barbash, J. E., Thelin, G. P., Kolpin, D. W., \& Gilliom, R. J. (2001). Major herbicides in groundwater: Results from the national water-quality assessment. Journal of Environmental Quality, 30(3), 831-845.

Cabrera, A., Cox, L., Spokas, K., Celis, R., Hermosin, C., Cornejo, J., et al. (2011). Comparative sorption and leaching study of the herbicides fluometuron and 4-chloro-2methylphenoxyacetic acid (MCPA) in a soil amended with biochars and other sorbents. Journal of Agricultural and Food Chemistry, 59(23), 12550-12560. 
Camobreco, V. J., Richards, B. K., Steenhuis, T. S., Peverly, J. H., \& McBride, M. B. (1996). Movement of heavy metals through undisturbed and homogenized soil columns. Soil Science, 161(11), 740-750.

Cao, X., Ma, L., Gao, B., \& Harris, W. (2009). Dairy-manure derived biochar effectively sorbs lead and atrazine. Environmental Science and Technology, 43(9), 3285-3291.

Chan, K. Y., Van Zwieten, L., Meszaros, I., Downie, A., \& Joseph, S. (2007). Agronomic values of greenwaste biochar as a soil amendment. Australian Journal of Soil Research, 45(8), 629634.

Chen, B., Zhou, D., \& Zhu, L. (2008). Transitional adsorption and partition of nonpolar and polar aromatic contaminants by biochars of pine needles with different pyrolytic temperatures. Environmental Science and Technology, 42(12), 5137-5143.

Chiou, C. T., \& Kile, D. E. (1998). Deviations from sorption linearity on soils of polar and nonpolar organic compounds at low relative concentrations. Environmental Science and Technology, 32(3), 338-343.

Cline, M. G., \& Bloom, A. L. (1966). Soil survey of cornell university property and adjacent areas. Cornell University, Ithaca, NY.: Cornell Miscellaneous Bulletin 68.

Dai, X., Boutton, T. W., Glaser, B., Ansley, R. J., \& Zech, W. (2005). Black carbon in a temperate mixed-grass savanna. Soil Biology and Biochemistry, 37(10), 1879-1881.

de Jonge, H., de Jonge, L. W., \& Jacobsen, O. H. (2000). (C-14)glyphosphate transport in undisturbed topsoil columns. Pest Management Science, 56(10), 909-915. 
Essington, M. E. (2004). Surface chemistry and adsorption reactions. Soil and water chemistry (pp. 311-398). Boca Raton, Florida: CRC Press LLC.

Flury, M. (1996). Experimental evidence of transport of pesticides through field soils - A review. Journal of Environmental Quality, 25(1), 25-45.

Flury, M., \& Qiu, H. (2008). Modeling colloid-facilitated contaminant transport in the vadose zone. Vadose Zone Journal, 7(2), 682-697.

Gao, J. P., Maguhn, J., Spitzauer, P., \& Kettrup, A. (1997). Distribution of pesticides in the sediment of the small teufelsweiher pond (southern Germany). Water Research, 31(11), 2811-2819.

Glaser, B., Lehmann, J., \& Zech, W. (2002). Ameliorating physical and chemical properties of highly weathered soils in the tropics with charcoal - a review. Biology and Fertility of Soils, 35(4), 219-230.

Gilliom et al. 2006, The Quality of Our Nation's Waters—Pesticides in the Nation's Streams and Ground Water, 1992-2001: U.S. Geological Survey Circular 1291, 172 p.

Jacobsen, O. H., Moldrup, P., Larsen, C., Konnerup, L., \& Petersen, L. W. (1997). Particle transport in macropores of undisturbed soil columns. Journal of Hydrology, 196(1-4), 185203.

Jarvis, N. J. (2007). A review of non-equilibrium water flow and solute transport in soil macropores: Principles, controlling factors and consequences for water quality. European Journal of Soil Science, 58(3), 523-546. 
Jia, Q., \& Lua, A. C. (2008). Effects of pyrolysis conditions on the physical characteristics of oilpalm-shell activated carbons used in aqueous phase phenol adsorption. Journal of Analytical and Applied Pyrolysis,83(2), 175-179.

Jones, D. L., Edwards-Jones, G., \& Murphy, D. V. (2011). Biochar mediated alterations in herbicide breakdown and leaching in soil. Soil Biology and Biochemistry, 43(4), 804-813.

Kookana, R. S., Sarmah, A. K., Van Zwieten, L., Krull, E., \& Singh, B. (2011). Biochar application to soil: Agronomic and environmental benefits and unintended consequences. Advances in Agronomy, 112, 103-143.

Kookana, R. S. (2010). The role of biochar in modifying the environmental fate, bioavailability, and efficacy of pesticides in soils: A review. Australian Journal of Soil Research, 48(6-7), $627-637$.

Lal, R. (2008). Carbon sequestration in soil. CAB Reviews: Perspectives in Agriculture, Veterinary Science, Nutrition and Natural Resources, 3(030), 20 pp.

Lasserre, J. -., Fack, F., Revets, D., Planchon, S., Renaut, J., Hoffmann, L., et al. (2007). Effects of the endocrine disruptors atrazine and PCB 153 on the protein expression of MCF-7 human cells. Journal of Proteome Research, 8(12), 5485-5496.

Lehmann, J., Gaunt, J., \& Rondon, M. (2006). Bio-char sequestration in terrestrial ecosystems a review. Mitigation and Adaptation Strategies for Global Change, 11(2), 403-427.

Lehmann, J. (2007). Bio-energy in the black. Frontiers in Ecology and the Environment, 5(7), $381-387$. 
Lehmann, J., \& Joseph, S. (2009). Biochar for environmental management: An introduction. In J. Lehmann, \& S. Joseph (Eds.), Biochar for environmental management science and technology (pp. 1-12). Sterling, VA: Earthscan.

Loganathan, V. A., Feng, Y., Sheng, G. D., \& Clement, T. P. (2009). Crop-residue-derived char influences sorption, desorption and bioavailability of atrazine in soils. Soil Science Society of America Journal, 73(3), 967-974.

Lohmann, R., MacFarlane, J. K., \& Gschwend, P. M. (2005). Importance of black carbon to sorption of native PAHs, PCBs, and PCDDs in Boston and New York harbor sediments. Environmental Science and Technology, 39(1), 141-148.

Lozano-Castelló, D., Lillo-Ródenas, M. A., Cazorla-Amorós, D., \& Linares-Solano, A. (2001). Preparation of activated carbons from spanish anthracite: I. activation by $\mathrm{KOH}$. CARBON, 39(5), 741-749.

Pignatello, J. J., Kwon, S., \& Lu, Y. (2006). Effect of natural organic substances on the surfaceand adsorptive properties of environmental black carbon (char): Attenuation of surface activity by humic and fulvic acids. Environmental Science and Technology, 40(24), $7757-7763$.

Qui, Y., Xiao, X., Cheng, H., Zhou, Z., \& Sheng, D. (2009). Influence of environmental factors on pesticide adsorption by black carbon: $\mathrm{PH}$ and model dissolved organic matter. Environmental Science and Technology, 43(13), 4973-4978. 
Rodionov, A., Amelung, W., Haumaier, L., Urusevskaja, I., \& Zech, W. (2006). Black carbon in the zonal steppe soils of russia. Journal of Plant Nutrition and Soil Science, 169(3), 363-369.

Seta A. K., \& Karathanasis A. D. (1997). Atrazine adsorption by soil colloids and co-transport through subsurface environments. Soil Science Society of America Journal, 61(2), 612-617.

Skjemstad, J. O., Taylor, J. A., Janik, L. J., \& Marvanek, S. P. (1999). Soil organic carbon dynamics under long-term sugarcane monoculture. Australian Journal of Soil Research, 37(1), 151-164.

Smernik, R. J. (2009). Biochar and sorption of organic compounds. Biochar for environmental management science and technology (pp. 289-300). Sterling, VA: Earthscan.

Sohi, S. P., Krull, E., Lopez-Capel, E., \& Bol, R. (2010). A review of biochar and its use and function in soil. Advances in Agronomy, 105, 47-82.

Spokas, K. A., Koskinen, W. C., Baker, J. M., \& Reicosky, D. C. (2009). Impacts of woodchip biochar additions on greenhouse gas production and sorption/degradation of two herbicides in a minnesota soil. Chemosphere, 77(4), 574-581.

Sprague, L. A., Herman, J. S., Hornberger, G. M., \& Mills, A. L. (2000). Atrazine adsorption and colloid-facilitated transport through the unsaturated zone. Journal of Environmental Quality, 29(5), 1632-1641.

Sun, K., Gao, B., Zhang, Z., Zhang, G., Zhao, Y., \& Xing, B. (2010). Sorption of atrazine and phenanthrene by organic matter fractions in soil and sediment. Environmental Pollution, 158(12), 3520-3526. 
Toxicological profile for atrazine (2003). U.S. Department of Health and Human Services.

Villholth, K., Jarvis, N., Jacobsen, O., \& de Jonge, H. (2000). Field investigations and modeling of particle-facilitated pesticide transport in macroporous soil. Journal of Environmental Quality, 29(4), 1298-1309.

Welhouse, G., J., \& Bleam, W. F. (1992). NMR spectroscopic investigation of hydrogen bonding in atrazine. Environmental Science and Technology, 26(5), 959-964.

Xing, B., Pignatello, J. J., \& Gigliotti, B. (1996). Competitive sorption between atrazine and other organic compounds in soils and model sorbents. Environmental Science and Technology, 30(8), 2432-2440.

Yang, Y. N., Sheng, G. Y., \& Huang, M. S. (2006). Bioavailability of diuron in soil contining wheat-straw-derived char. The Science of the Total Environment, 354(2-3), 170-178.

Yu, X., Ying, G., \& Kookana, R. S. (2009). Reduced plant uptake of pesticides with biochar additions to soil. Chemosphere, 76(5), 665-671.

Zhang, W., Niu, J., Morales, V. L., Chen, X., Hay, A. G., Lehmann, J., et al. (2010). Transport and retention of biochar particles in porous media: Effect of $\mathrm{pH}$, ionic strength, and particle size. Ecohydrology, 3(4), 497-508.

Zheng, W., Guo, M., Chow, T., Bennett, D. N., \& Rajagopalan, N. (2010). Sorption properties of greenwaste biochar for two triazine pesticides. Journal of Hazardous Materials, 181(1-3), $121-126$. 